\title{
At-Taqaddum
}

Vol. 11 No. 2 (2019) pp 186-233

DOI: http://dx.doi.org/10.21580/at.v11i2.4566

\section{ANALISIS FAKTOR-FAKTOR PENGHAMBAT PENYELESAIAN SKRIPSI MAHASISWA JURUSAN BIMBINGAN DAN PENYULUHAN ISLAM FAKULTAS DAKWAH DAN KOMUNIKASI UIN WALISONGO SEMARANG}

Anila Umriana

Fakultas Dakwah dan Komunikasi UIN Walisongo Semarang

Email: anilaumriana@walisongo.ac.id

\begin{abstract}
One of the problem related with finishing the study is writing the thesis. In fact, the percentage of BPI students who can finish their thesis on time is too less than thoose are late in finishing them. This research is purposed to find out and analize the resisting factors in finishing the thesis. This research is qualitative descriptive research. The premary data resources are the students of BPI department those have more than one year in finishing their thesis. The secondary data resources are the advisors and the related documents. The result of the research shows that there are ten inbibiting factors in finishing thesis of BPI FDK students of UIN Walisongo Semarang. The reseacher classified those factors into two categories, they are internal and external factors. The internal factors are health, psychological obstacles, academic ability, and approachment (attitude and learning habit). The external factors are related with family, environment/ friends, the administrative system of thesis, the process of lecturer's advising, references and other activities.
\end{abstract}

Keyword: internal factor, resisting factors, finishing the thesis, 


\begin{abstract}
Abstrak
Salah satu problem yang berkaitan dengan penyelesaian studi adalah penulisan dan penyelesaian skripsi. Faktanya, persentase mahasiswa jurusan BPI yang mampu menyelesaikan skripsi tepat waktu jauh lebih kecil daripada jumlah mahasiswa yang mengalami keterlambatan. Penelitian ini bertujuan untuk menemukan dan menganalisis faktor-faktor yang menjadi penghambat penyelesaian skripsi tersebut. Penelitian ini merupakan penelitian kualitatif desktiptif. Sumber data primer yaitu mahasiswa jurusan BPI yang waktu tempuh skripsinya lebih dari satu tahun. Sumber data sekundernya adalah dosen pembimbing, dan dokumen terkait. Hasil penelitian menunjukkan bahwa ada sepuluh faktor yang menghambat penyelesaian skripsi mahasiswa jurusan BPI FDK UIN Walisongo Semarang. Dari sepuluh faktor tersebut peneliti mengelompokkan menjadi dua bagian, yaitu faktor internal dan faktor eksternal. Faktor internal berupa; kesehatan, hambatan psikologis, kemampuan akademik, dan pendekatan (sikap dan kebiasaan belajar). Sedangkan faktor eksternal berupa; keluarga, lingkungan/teman, sistem admnistrasi skripsi, proses pembimbingan dosen, referensi, dan aktifitas lain.
\end{abstract}

$\begin{aligned} \text { Kata Kunci: } & \begin{array}{l}\text { Faktor internal, faktor penghambat, } \\ \text { penyelesaian skripsi }\end{array}\end{aligned}$

\title{
Pendahuluan
}

Salah satu tahapan yang harus diselesaikan mahasiswa S1 untuk mendapatkan gelar sarjana adalah penulisan skripsi. Skripsi merupakan karya ilmiah yang ditulis berdasarkan hasil penelitian dengan bimbingan dosen yang ditunjuk dalam rangka penyelesaian program sarjana Strata 1 (S1). Tema skripsi disesuaikan dengan kajian 


\section{At-Taqaddum}

Vol. 11 No. 2 (2019) pp 186-233

DOI: http://dx.doi.org/10.21580/at.v11i2.4566

atau kompetensi utama yang relevan dengan program studi. ${ }^{1}$ Penulisan skripsi bertujuan untuk memberikan pengalaman belajar kepada mahasiswa dalam menyelesaikan masalah ilmiah dengan cara melakukan penelitian sendiri, menganalisis dan menarik kesimpulan, serta menyusunnya menjadi bentuk karya ilmiah. ${ }^{2}$

Universitas Islam Negeri Walisongo telah mengatur tentang sistem dan prosedur penulisan skripsi dalam Buku Panduan Program Sarna (S1) dan Diploma 3 (D3) yang diterbitkan setiap tahun. Aturan tersebut dirinci dalam Pedoman Akademik UIN dan Buku Panduan Akademik Jurusan BPI yang memuat tentang aturan, sistem, prosedur dan alur penulisan skripsi mulai tahapan usulan judul sampai dengan ujian munaqasah. Selain itu, Fakultas Dakwah dan Komunikasi juga menerbitkan panduan khusus tentang penulisan skripsi yang memuat ketentuan umum (prosedur pengajuan judul, usulan proposal, prosedur penulisan skripsi, pembimbing, dan ujian skripsi), sistematika proposal, skripsi, dan tata cara penulisan. ${ }^{3}$

Pada umumnya skripsi ditempuh mahasiswa pada semester tujuh dan delapan. Berdasarkan standar akreditasi program studi sarjana sebagaimana yang ditetapkan oleh Badan Akreditasi Nasional Perguruan Tinggi (BAN-PT) dengan menggunakan standar akreditasi 3.0 yang termuat dalam Standar 5 (Kurikulum, pembelajaran, dan suasana akademik) yaitu point 5.5.2 menyatakan bahwa waktu ideal yang diharapkan dalam penyelesaian tugas akhir (skripsi) adalah enam bulan. ${ }^{4}$ Namun pada kenyataannya sebagian besar mahasiswa jurusan BPI FDK UIN walisongo menyelesaikan penulisan skripsi lebih dari

1 Buku Panduan Program Sarjana (S1) dan Diploma (D3) Tahun Akademik 2015/2016. Hlm 170-171

${ }^{2}$ Julita dkk. 2015. Faktor Penghambat dalam penyelesaian Skripsi Mahasiswa Jurusan Kesejahteraan Keluarga. Padang: Universitas negeri Padang.

3 Lihat Buku Panduan Program Sarjana Tahun Akademik 2015/2016 UIN Walisongo, Pedoman Akademik IAIN Walisongo Tahun 2014, Buku Panduan Akademik Jurusan BPI FDK, dan Buku Panduan Skripsi Fakultas Dakwah dan Komunikasi UINWalisongo Tahun 2015.

${ }^{4}$ BAN PT - Buku 6 Matriks Penilaian Instrumen Akreditasi Program Studi Sarjana, 2008, hlm 24 
enam bulan. Berdasarkan data lulusan periode Wisuda Januari 2017, menunjukkan bahwa rata-rata mahasiswa menyelesaikan penulisan skripsi selama empat belas bulan. ${ }^{5}$ Tercatat penulisan skripsi tercepat dilakukan selama delapan bulan dan yang paling lama selama tigapuluh bulan $(2,5$ tahun $){ }^{6}$

Selain itu, berdasarkan data wisudawan setiap semester, diperoleh data tentang waktu penyelesaian studi mahasiswa BPI. Pada tahun 2015-2017, rata-rata mahasiswa jurusan BPI menyelesaikan studi ditunjukkan pada tabel berikut:

Tabel 1. Persentase waktu penyelesaian studi mahasiswa jur BPI

\begin{tabular}{|c|c|c|c|c|}
\hline $\begin{array}{c}\text { Periode } \\
\text { wisuda }\end{array}$ & $\begin{array}{c}\text { Lama studi } \\
\text { - persen }\end{array}$ & $\begin{array}{c}\text { Lama studi } \\
- \text { persen }\end{array}$ & $\begin{array}{c}\text { Lama studi } \\
\text { - persen }\end{array}$ & $\begin{array}{c}\text { Lama studi - } \\
\text { persen }\end{array}$ \\
\hline \multirow{2}{*}{ Januari 2017} & 4,5 tahun & 5,5 tahun & 6,5 tahun & 7,5 tahun* \\
& $62 \%$ & $14 \%$ & $24 \%$ & $0 \%$ \\
\hline \multirow{2}{*}{ Juli 2016} & 4 Tahun & 5 tahun & 6 tahun & 7 tahun \\
& $10 \%$ & $60 \%$ & $17 \%$ & $13 \%$ \\
\hline \multirow{2}{*}{ Januari 2016} & 4,5 tahun & 5,5 tahun & 6,5 tahun & 7,5 tahun* \\
& $41 \%$ & $33 \%$ & $19 \%$ & $7 \%$ \\
\hline \multirow{2}{*}{ Juli 2015} & 4 tahun & 5 tahun & 6 tahun & 7 tahun \\
& $29 \%$ & $50 \%$ & $12 \%$ & $9 \%$ \\
\hline \multirow{2}{*}{ Januari 2015} & 4,5 tahun & 5,5 tahun & 6,5 tahun & 7,5 tahun* \\
& $59 \%$ & $38 \%$ & $0 \%$ & $3 \%$ \\
\hline \multirow{2}{*}{ Agustus 2014} & 4 tahun & 5 tahun & 6 tahun & 7 tahun \\
& $12 \%$ & $62 \%$ & $12 \%$ & $14 \%$ \\
\hline
\end{tabular}

*Mahasiswa menyelesaikan skripsi pada akhir semester XIV, namun mengikuti wisuda berikutnya (Sumber: Dokumen Laporan Wakil Dekan I setiap periode wisuda)

Tabel tersebut menunjukkan bahwa persentase mahasiswa lulus tepat waktu (empat tahun) masih sangat sedikit. Salah satu yang menjadi kendala penyelesaian studi adalah berkaitan dengan penelitian atau penulisan skripsi mahasiswa. Berbagai kendala yang dihadapi

5 Waktu tersebut dihitung sejak judul proposal di ditujui oleh jurusan sampai dengan waktu pelaksanaan ujian munaqasah.

${ }^{6}$ Data Rekapitulasi pengajuan judul skripsi dan kendali penunjukan pembimbing skripsi jurusan BPI. 


\section{At-Taqaddum}

Vol. 11 No. 2 (2019) pp 186-233

DOI: http://dx.doi.org/10.21580/at.v11i2.4566

mahasiswa dalam penyelesaian tugas akhir (skripsi). Hasil penelitian Kusnendar dkk menunjukkan bahwa ada dua faktor penghambat penyelesaian studi mahasiswa yaitu faktor internal dan eksternal. Faktor internal meliputi: faktor kesehatan, faktor psikologis, dan faktor kelelahan, sedangkan faktor eksternal meliputi: faktor, keluarga, teman bergaul, pembimbingan dengan dosen, kesulitan referensi, dan persoalan administratif. ${ }^{7}$ Selain itu, menurut Slamet (dalam Putri dan Savira, 2013) menyatakan bahwa, pada umumnya, mahasiswa mengalami kesulitan dalam tulis menulis, kemampuan akademik yang tidak memadai, adanya kurang ketertarikan mahasiswa pada penelitian, serta kegagalan mencari judul skripsi, kesulitan mencari literatur, dan bahan bacaan, serta kesulitan menemui dosen pembimbing. ${ }^{8}$

Penelitian lain menunjukkan bahwa tipe kepribadian mahasiswa juga berpengaruh terhadap proses penyelesaian skripsi. Mahasiswa introvert memiliki kecenderungan yang lebih besar dalam melakukan prokrastinasi (penundaan) tugas skripsi dibandingkan mahasiswa ekstrovert. Hal ini disebabkan karena performansi individu ekstrovert pada aktifitas motorik akan terlihat lebih bertenaga, dan lebih cepat berinisiatif dalam bergerak. Sebaliknya individu dengan tipe kepribadian introvert cenderung memperlambat gerak mereka pada aktifitas motorik. Selain itu, diperoleh hasil bahwa semakin tinggi angkatan seorang mahasiswa maka semakin besar kemungkinan melakukan prokrastinasi tugas skripsi. ${ }^{9}$

7 Febriyanto Kusnendar, Suwachid, dan Danar Susilo Wijayanto. 2012. Analisis Penghambat Penyelesaian Studi Mahasiswa S1 Program Studi Pendidikan Teknik Mesin Jurusan Pendidikan Teknik dan Kejuruan Fakultas keguruan dan Ilmu Pendidikan Universitas Sebelas Maret Surakarta. Hasil Penelitian.

${ }^{8}$ Putri dan Savira. 2013. Pengalaman Menyelesaikan Skripsi: Studi Fenomenologis pada Mahasiswa Psikologi Universitas Negeri Surabaya, dalam Jurnal Character. Volume 02 Nomor 02 Tahun 2013. pp. 1

9 Linda Catrunada. 2007. Perbedaan Kecenderungan Prokrastinasi Tugas Skripsi Berdasarkan Tipe Kepribadian Introvert dan Ekstrovert. Skripsi Fakultas Psikologi Universitas Gunadarma 
Studi yang lain menyebutkan bahwa profil dosen pembimbing juga turut berperan dalam proses penyelesaian skripsi mahasiswa. Hasil penelitian Ike Ratnawati menyatakan bahwa profil akademik dosen pembimbing skripsi tidak dianggap sebagai faktor yang terlalu dominan yang diharapkan mahasiswa dapat membantu penyelesaian skripsinya. Mahasiswa mengidentifikasi profil personal/kepribadian dosen pembimbing yang dapat memotivasinya dalam penyelesaian skripsi yakni dosen pembimbing yang perhatian, konsekuen, jujur, komunikasi yang baik, nyaman, lancar, hangat, bersahabat, nyantai, mudah, tidak terlalu formal, tidak terlalu ketat, tidak terlalu birokratis, bisa bersikap sebagai teman yang siap membantu memecahkan penyelesaian skripsi mahasiswa, tegas, disiplin, mudah ditemui di kampus, dan bisa membuat janji di luar kampus sewaktu-waktu mahasiswa membutuhkan. ${ }^{10}$

Berdasarkan beberapa hasil peneltian tersebut dapat dilihat bahwa proses penyelesaian skripsi mengalami berbagai kendala yang sangat beragam. Secara umum faktor yang menjadi penghambat terbagi menjadi dua yaitu faktor internal dan eksternal. Dari wawancara pendahuluan yang dilakukan oleh peneliti kepada beberapa mahasiswa jurusan BPI yang sedang menempuh skripsi menyatakan bahwa sebagian mengalami kendala karena memiliki aktifitas lain seperti bekerja, berorganisasi dan lainnya. Sedangkan sebagian yang lain mengaku merasa stres dalam penyusunan proposal dan proses pembimbingan. ${ }^{11}$

Berangkat dari kondisi di atas, perlu dilakukan penelitian untuk mengungkap faktor-faktor apa yang menjadi penghambat penyelesaian skripsi mahasiswa jurusan BPI. Hasil penelitian ini nantinya diharapkan sebagai informasi dan bahan untuk bagi pengelola jurusan BPI untuk menindaklanjuti dan melakukan

${ }^{10}$ Ike Ratnawati. 2007. Pendapat Mahasiswa Jurusan Seni dan Desain tentang Profil Dosen Pembimbing Skripsi yang dapat Membantu Penyelesaian Skripsinya. Malang: Universitas Negeri Malang.

${ }^{11}$ Hasil wawancara dengan mahasiswa jurusan BPI angkatan 2012 


\section{At-Taqaddum}

Vol. 11 No. 2 (2019) pp 186-233

DOI: http://dx.doi.org/10.21580/at.v11i2.4566

kebijakan dan menentukan langkah-langkah solusinya. Oleh karena itu, penelitian ini sangat penting dilakukan agar penulisan skripsi bukan menjadi halangan bagi mahasiswa untuk menyelesaikan studinya.

Penelitian ini merupakan penelitian kualitatif deskriptif. Penelitian kualititatif bertujuan untuk menganalisis berdasarkan data yang diperoleh, mengembangkan pola hubungan tertentu sehingga dapat menjawab pertanyaan penelitian melalui cara-cara berfikir argumentatif. ${ }^{12}$ Sedangkan deskripstif yaitu penelitian ini berusaha memberikan pemecahan masalah yang ada berdasarkan data yang ditemukan. ${ }^{13}$ Penelitian ini akan memaparkan tentang faktor-faktor penghambat yang dialami mahasiswa jurusan BPI dalam penyelesaian skripsi.

Sumber data primer dalam penelitian ini adalah mahasiswa jurusan BPI yang menyelesaikan penulisan skripsi lebih dan satu tahun dan dosen pembimbing. Data primer berupa; pertama, hasil wawancara dengan mahasiswa dan dosen pembimbing. Kedua, hasil angket yang diberikan kepada mahasiswa.Sumber data sekunder; data yang mendukung data primer dan dapat diperoleh dari luar objek penelitian. Data sekunder didapatkan secara tidak langsung memberikan data kepada pengumpul data. ${ }^{14}$ Data ini meliputi hasil observasi pada saat pengajuan judul, ujian komprehensif dan ujian munaqasah, buku-buku, dokumen, literatur, review, penelitian ataupun sumber lain yang berkaitan dengan permasalahan penulisan skripsi.

Teknik pengumpulan data yang digunakan dalam penelitian ini yaitu:

${ }^{12}$ Sugiyono. 2007. Metode Penelitian Pendidikan Pendekatan Kuantitatif, Kualitatif dan R \& D. Bandung: Alfabeta. Hlm. 335.

13 Cholid Narbuko dan Abu Ahmadi. 2005. Metodologi Penelitian. Jakarta: Bumi Aksara.

${ }^{14}$ Sugiyono. hlm 309. 
a. Wawancara, dilakukan kepada mahasiswa yang menyelesaikan skripsi selama lebih dari satu tahun (terhitung dari judul diacc sampai dengan ujian munaqasah)

b. Angket, digunakan untuk mendapatkan gambaran umum tentang faktor - faktor yang menjadi kendala bagi mahasiswa dalam menyelesaikan skripsi. Angket yang digunakan merupakan angket semi terbuka, yaitu angket yang bentuk jawabannya merupakan gabungan antara angket tertutup dan terbuka. Angket jenis ini menyediakan jawaban dan memberikan ruang untuk jawaban tambahan.

c. Dokumentasi yaitu proses pengumpulan dan pengelolaan data secara sistematis. Teknik ini digunakan untuk mengetahui sistem dan prosedur penulisan skripsi di Jurusan BPI FDK UIN Walisongo.

d. Observasi, dilakukan sebagai teknik pengumpulan data tambahan untuk mengamati perilaku mahasiswa yang akan atau sedang melakukan proses bimbingan skripsi. Observasi dilakukan pada saat pengajuan judul, ujian komprehensif, dan ujian munaqasah.

\section{Hasil Penelitian}

Penelitian ini dilaksanakan pada tahun 2017. Subyek penelitian ini adalah mahasiswa yang telah lulus pada periode wisuda Juli 2017 yang berjumlah 43. Dari 43 mahasiswa tersebut 34 diantaranya waktu tempuh skripsinya lebih dari 1 tahun. Angket disebarkan kepada 34 mahasiswa tersebut dan 5 diantaranya tidak kembali, sehingga total angket yang terkumpul sejumlah 29. Berdasarkan angket tersebut peneliti kemudian melakukan wawancara mendalam untuk mengelaborasi dan menggali data lebih dalam terkait dengan faktorfaktor tersebut.

Adapun data informan dalam penelitian ini sejumlah 11 Mahasiswa dan 5 orang dosen pembimbing. Pemilihan informan 


\section{At-Taqaddum}

Vol. 11 No. 2 (2019) pp 186-233

DOI: http://dx.doi.org/10.21580/at.v11i2.4566

menggunakan snowball sampling. Berdasarkan hasil angket, wawancara dan observasi diperoleh data tentang faktor yang menghambat penyelesaian skripsi mahasiswa sebagai berikut:

\section{Faktor kesehatan}

Berdasarkan data hasil penelitian, faktor kesehatan merupakan salah satu kendala dalam penyelesaian skripsi. Dari 29 mahasiswa, empat orang diantaranya (13.8\%) menyatakan bahwa kesehatan juga menjadi kendala dalam proses penyelesaian skripsi. Faktor kesehatan yang dimaksud meliputi, sering pusing, kurang fit, dan mudah mengalami kelelahan.

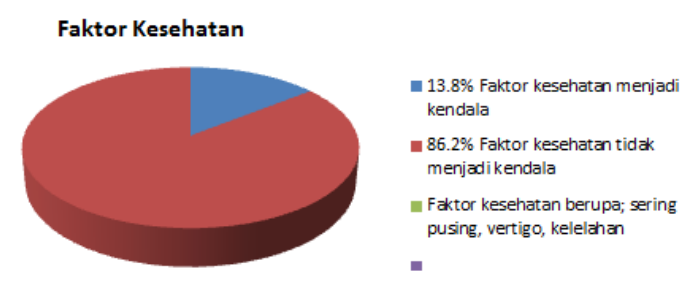

\section{Faktor hambatan psikologis}

Berdasarkan hasil angket yang diberikan kepada 29 responden, 26 diantaranya $(89,6 \%)$ menyatakan bahwa hambatan psikologis menjadi salah satu kendala dalam penyelesaian skripsi, dan hanya 3 orang saja yang mengaku hal ini tidak berkaitan dengan penyelesaian skripsi. Faktor hambatan psikologis tersebut berupa, kemalasan, kurang motivasi, sulit berkonsentrasi, menunda-nunda mengerjakan, menyepelekan, dan kekhawatiran terhadap hasil ujian skripsi. 
Faktor kemalasan dan kurang motivasi menjadi kendala yang sering dialami mahasiswa yang sedang menyelesaikan skripsi. Hal ini muncul disebabkan karena pada saat mengerjakan skripsi tidak ada target yang jelas, sehingga seringkali menunda-nunda waktu untuk mengerjakannya, sehingga tanpa disadari telah menghabiskan waktu yang lama untuk menyelesaikannya. Perubahan mood yang dialami mahasiswa juga sangat berpengaruh dalam mengerjakan skripsi, pada saat pikirannya sedang nyaman dan bersemangat, maka ia akan sangat bersemangat dalam mengerjakan dan menyelesaikan skripsi, tapi jika kondisi psikologisnya sedang tidak nyaman, maka keinginannya untuk mengerjakan skripsi jadi menghilang juga. Perubahan kenyamanan psikologis yang dialami, disebabkan oleh beberapa faktor diantara, suasana hati yang sedang sedang, lingkungan kost, keluarga dan juga proses bimbingannya.

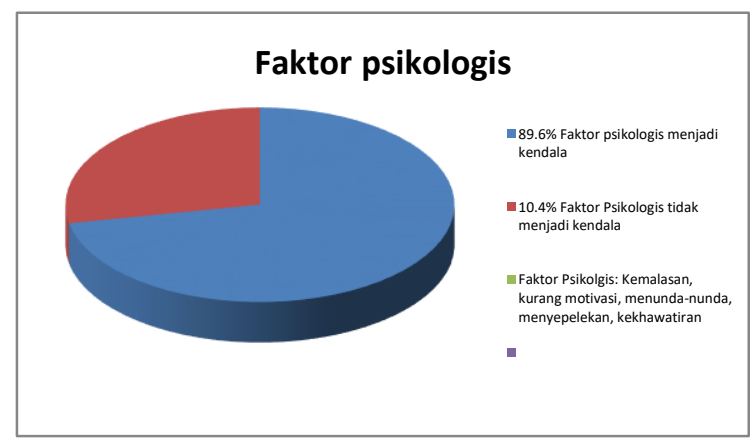

\section{Faktor kemampuan akademik}

Kemampuan akademik merupakan kapasitas mahasiswa yang berkaitan dengan penguasaan terhadap kompetensi tertentu. Kemampuan akademik yang dimaksud dalam penelitian ini berkenaan dengan problem yang dihadapi mahasiswa dalam menyelesaikan skripsi seperti kesulitan dalam metodologi penelitian, keterbatasan dalam hal kemampuan tulis menulis dan lain sebagainya. 


\section{At-Taqaddum}

Vol. 11 No. 2 (2019) pp 186-233

DOI: http://dx.doi.org/10.21580/at.v11i2.4566

Berdasarkan angket yang diberikan kepada 29 mahasiswa, 21 diantaranya $(72,4 \%)$ menyatakan bahwa kemampuan akademik menjadi salah satu kendala dalam penyelesaian skripsi, dan 8 orang lainnya mengaku hal ini tidak berkaitan dengan penyelesaian skripsi. Faktor kemampuan akademik tersebut berupa; kesulitan menemukan masalah penelitian, kesulitan dalam menerapkan metodologi penelitian, kemampuan menulis yang terbatas, kesulitan dalam hal menuangkan gagasan, serta kendala dalam hal penguasaan bahawa asing.

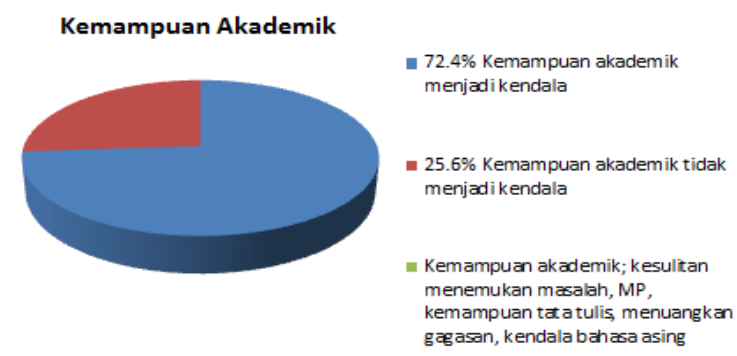

\section{Faktor pendekatan belajar}

Pendekatan belajar berkaitan dengan cara yang digunakan seseorang dalam proses belajarnya. Pendekatan belajar yang dimaksud dalam hal ini berkaitan dengan sikap atau tindakan yang dilakukan dalam proses penyelesaian skripsi. Berdasarkan angket yang diberikan kepada 29 mahasiswa, 22 diantaranya (75,9\%) menyatakan bahwa pendekatan belajar menjadi salah satu kendala dalam penyelesaian skripsi, dan 7 orang lainnya mengaku hal ini tidak berkaitan dengan penyelesaian skripsi. Pendekatan belajar yang dimaksud berupa; minat baca yang rendah, kesulitan membagi waktu, kurangnya teman untuk berdiskusi, dan kurangnya kesungguhan dalam mengerjakan skripsi. 
Rendahnya minat membaca merupakan salah satu kendala dalam hal penyelesaian skripsi. Hal ini disebabkan karena budaya/iklim akademik yang kurang mendukung dan sulitnya referensi tentang tema-tema tertentu. Rendahnya minat baca ini berakibat pada elaborasi permasalahan penelitian menjadi dangkal serta kesulitan dalam melakukan analisis yang disebabkan karena minimnya literature yang dibaca. Kesulitan membagi waktu juga menjadi kendala. Hal ini dikarenakan mahasiswa harus berbagi beberapa aktifitas lain, seperti; bekerja (yang sifatnya fulltime), mengurus keluarga, kegiatan di organisasi mahasiswa ataupun organisasi kemasyarakatan. Pekerjaan yang full-time menjadikan mahasiswa mengalami kesulitan untuk mengatur waktu atau meluangkan waktu untuk mengerjakan skripsi. Beberapa diantaranya mengalami kelelahan setelah bekerja seharian, sedangkan yang lain merasa kesulitan membagi waktu karena pekerjaan yang dijalani jauh dari kampus. Faktor lainnya karena kurang disiplin dalam mengatur dirinya sendiri. Beban pekerjaan dalam keluarga juga menjadi salah satu penyebabnya sehingga mengabaikan proses skripsi.

Selain faktor minimnya minat baca dan sulitnya membagi waktu, kurangnya diskusi juga menjadi kendala yang berkaitan dengan pendekatan belajar. Hal ini disebabkan oleh beberapa hal, diantaranya; mahasiswa sudah kembali ke rumah dan intensitas ke kampus rendah sehingga jarang bertemu dengan teman-temannya. Kedua, bagi mahasiswa yang berada disemester akhir, kurangnya diskusi disebabkan karena sebagian besar teman-temannya sudah lulus sehingga tidak ada lagi yang dapat dijadikan teman untuk berdiskusi. 


\section{At-Taqaddum}

Vol. 11 No. 2 (2019) pp 186-233

DOI: http://dx.doi.org/10.21580/at.v11i2.4566

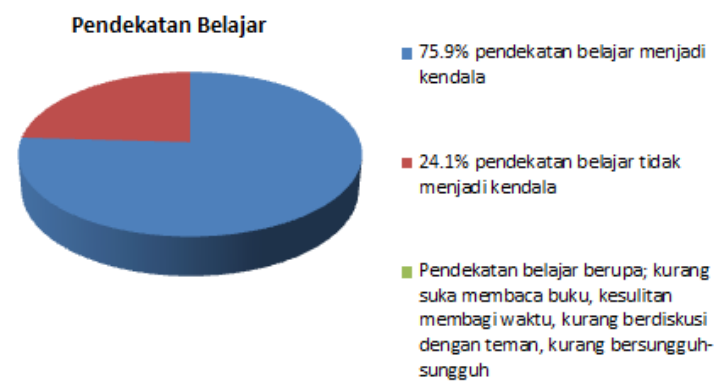

\section{Faktor Lingkungan Keluarga}

Keluarga merupakan lingkungan terdekat mahasiswa di rumah. Dinamika dan problematika yang terjadi dalam keluarga secara langsung atau tidak langsung dapat berpengaruh terhadap anaknya. Sebagian mahasiswa yang mengerjakan skripsi tinggal bersama dengan orang tua sedangkan sebagian yang lain tinggal di lingkungan kost atau pondok. Sebanyak 34,5\% mahasiswa mengaku bahwa faktor keluarga menjadi salah satu kendala dalam penyelesaian skripsi. Faktor keluarga tersebut berupa, kurangnya motivasi orang tua, kurang dukungan finansial dari orang tua, serta tekanan dari orang tua agar segera lulus.

Kurangnya motivasi dari orang tua tersebut ditandai dengan minimnya perhatian dari orang tua tentang persoalan-persoalan yang dihadapi mahasiswa dalam menyelesaikan skripsinya. Selain itu, orang tua juga tidak tahu menahu tentang proses atau tahapan yang harus dilalui mahasiswa dalam menyusun skripsi. Selain kurangnya motivasi, dukungan finansial yang terbatas dari orang tua juga jadi kendala. Sebagaimana diketahui bahwa proses penulisan skripsi membutuhkan dana yang lebih untuk cetak naskah (ngeprint), buku-buku referensi, sering foto kopi karena seringnya revisi, dan untuk operasional lainnya. Kendala lainnya 
dialami adalah adanya problem dalam keluarga, desakan dari kelurga agar segera lulus, dan membantu pekerjaan di rumah.

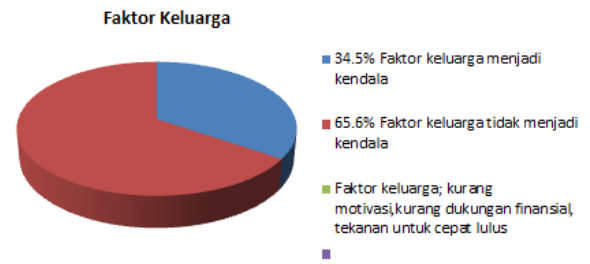

\section{Faktor Lingkungan/teman}

Selain lingkungan keluarga, lingkungan kost dan teman juga menjadi faktor yang mempengaruhi dalam penyelesaian skripsi. Bagi mahasiswa yang tinggal di kost atau di pondok, situasi lingkungan tersebut juga menjadi kendala (37,9\%). Lingkungan tempat tinggal dan teman yang menjadi kendala dan hambatan tersebut berupa; situasi kost yang ramai, tidak kondusif untuk mengerjakan skripsi, teman yang sering mengajak jalan (melakukan aktifitas yang kurang penting), dan teman yang sama-sama malas mengerjakan skripsi.

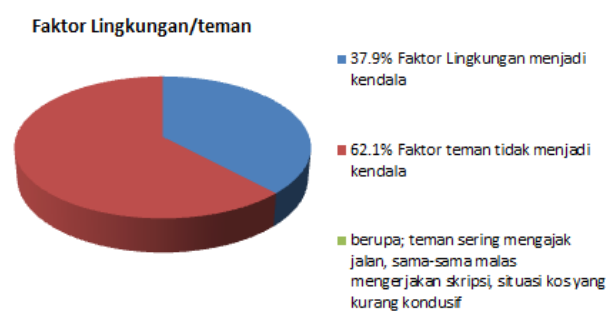




\section{At-Taqaddum}

Vol. 11 No. 2 (2019) pp 186-233

DOI: http://dx.doi.org/10.21580/at.v11i2.4566

\section{Faktor Sistem Administrasi Skripsi}

Proses penyusunan dan penyelesaian skripsi tidak bisa dilepaskan dari sistem administrasinya. Berdasarkan angket diperoleh data bahwa 17 dari 29 mahasiswa mengaku bahwa sistem administrasi skripsi menjadi salah satu kendala dalam penyelesaian skripsi. Artinya 58,6\% mahasiswa mengalami kendala dalam sistem administrasi skripsi yang berpengaruh terhadap penyelesaian skripsi, sedangkan sisanya sebesar $41,4 \%$ mengaku bahwa sistem administrasi skripsi tidak menjadi kendala dalam penyelesaian skripsinya.

Kendala yang berkaitan dengan sistem adminstrasi skripsi tersebut berupa; proses perijinan dan surat menyurat yang lama, berkas persyaratan untuk ujian yang banyak, upload dokumen ujian yang sulit karena jaringan yang sering eror, sistem yang tidak terintegrasi antara fakultas dan pusat bahasa, dan masalah syarat TOEFL_IMKA.

Pada sisi yang lain, berkas persyaratan ujian yang cukup banyak serta keharusan upload dokumen secara online dirasakan juga menjadi kendala disebabkan jaringan yang eror. Selain itu, mahasiswa juga harus membawa berkas ijazah untuk discan baru kemudian bisa diupload. Selain itu, persyaratan IMKA dan TOEFL yang diberlakukan mulai angkatan 2012 dirasakan juga menjadi kendala. Tidak semua mahasiswa menguasai bahasa asing tersebut dengan baik. Sebagian kemampuannya sangat minim, sehingga harus ujian berkali-kali bahkan ada yang sampai 6 kali. Kurangnya sosialisasi diawal menjadikan mahasiswa kurang memiliki persiapan yang lebih dini. Kendala lain berkaitan dengan antrian ujian yang cukup lama, selain faktor pendaftaran yang harus perkelompok dan mahasiswa harus mencari kelompok sendiri. Selain itu juga sosisalisasi tentang kebijakan TOEFL dan IMKA juga tidak dilakukan sejak awal sehingga mahasiswa tidak bisa mempersiapkan sejak awal. 


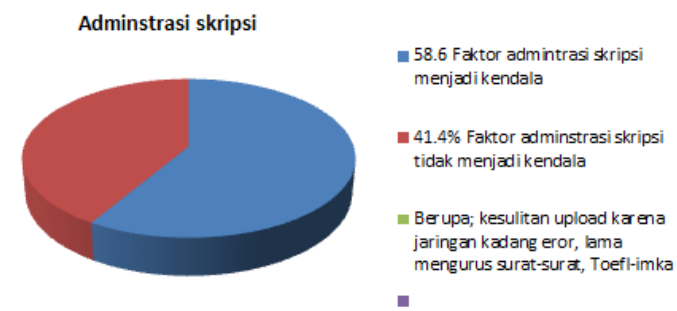

\section{Faktor Referensi}

Referensi merupakan salah satu hal yang mutlak diperlukan dalam proses penulisan skripsi. Tanpa adanya referensi yang memadai, mustahil skripsi akan dapat diselesaikan. Ketersedian referensi yang cukup menjadi salah satu kebutuhan mendasar dalam mengembangkan kerangka teori skripsi. Berdasarkan temuan penelitian, ketersediaan referensi yang dapat dijadikan rujukan penelitian di lingkungan UIN walisongo ditambah lagi dengan perpustakaan wilayah dirasakan cukup memadai. Kendala dijumpai hanya pada tema-tema tertentu yang memang referensi tersebut tidak dijual secara bebas, misalnya terkait dengan bimbingan di LAPAS, Rumah Sakit dan lainnya. Adapun tema-tema umum tentang studi kefakultasan dan kejurusanan dipandang cukup memadai.

Beberapa mahasiswa $(58,6 \%)$ yang memiliki kendala terkait dengan referensi ini mengaku mengalami kesulitan dalam hal; mencari buku-buku teks induk yang jumlahnya terbatas di perpustakaan, selain itu juga terkadang buku yang dibutuhkan tersebut sedang dipinjam orang lain.

Persoalan lain yang dijumpai adalah larangan untuk membawa pulang literature dengan kode tertentu sehingga 


\section{At-Taqaddum}

Vol. 11 No. 2 (2019) pp 186-233

DOI: http://dx.doi.org/10.21580/at.v11i2.4566

mahasiswa hanya bisa membaca ditempat, atau menulis, dan atau memfoto buku tersebut. Hal ini dirasakan kurang efektif karena pemahaman mahasiswa tentang keseluruhan teks tersebut menjadi kurang komprehensif.

\section{Faktor bimbingan dosen}

Proses bimbingan tidak bisa dilepaskan dari proses penyusunan, dan penyelesaian skripsi. Pembimbingan skripsi dilakukan oleh dua orang dosen pembimbing. Pembimbing 1 bidang subsansi materi dan pembimbing 2 bidang metodologi penelitian dan tata tulis. Berdasarkan temuan penelitian diperoleh data bahwa faktor pembimbingan menjadi salah satu kendala dalam penyelesaian skripsi. Sebesar $62.1 \%$ menyatakan bahwa proses pembimbingan menjadi kendala, sedangkan sisanya, sebesar 37.9\% mengaku tidak menjadi kendala.

Kendala yang berkaitan dengan faktor pembimbingan dosen, berupa: lamanya naskah dikoreksi, 'takut' menemui dosen, dosen memiliki kesibukan yang beragam, dosen sulit ditemui, keterbatasan waktu bimbingan, perbedaan pendapat antara pembimbing 1 dan 2 , kurang masukan dosen, tidak paham masukan dosen.

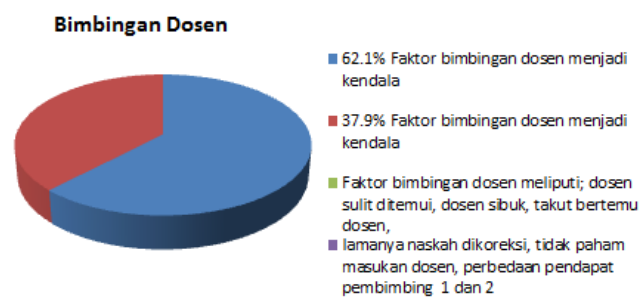




\section{Faktor kegiatan/aktifitas lain}

Faktor lainnya adalah berkaitan dengan kegiatan atau aktifitas lain yang dilakukan oleh mahasiswa selain kuliah. Sejumlah 65,5\% menyatakan bahwa aktivitas lain menjadi kendala dalam penyelesaian skripsi. Aktifitas tersebut antara lain; bekerja (full time maupun part time), aktif di organisasi kemahasiswaan, aktif dalam organisasi kemasyarakatan, dan membantu orang tua di rumah.

Kuliah sambil bekerja diakui menjadi salah satu kendala dalam penyelesaian skripsi. Kesulitan membagi waktu merupakan salah satu penyebabnya disamping faktor kelelahan yang mengakibatkan setelah bekerja sudah enggan untuk mengerjakan skripsi yang berakibat pada tertundanya penyelesaian skripsi. Selain itu aktifitas di orgnisasi baik organisasi kemahasiswaan maupun organisasi kemasyarakatan juga diraakan menjadi kendala karena kesulitan dalm mebagi waktu.

Dari uraian diatas dapat diketahui bahwa faktor-faktor yang menghambat penyelesaian skripsi ada sepuluh, yaitu pertama, faktor kesehatan yang berupa pusing dan kelelahan. Kedua, faktor hambatan psikologis yang berupa, kemalasan, kurangnya motivasi, tidak bersemangat, stress dan cemas. Ketiga, faktor kemampuan akademik, yang meliputi; kesulitan tata tulis, minimnya penguasaan metodologi penelitian, kesulitan menuangkan gagasan, kemampuan membaca al quran, dan kendala Bahasa asing. Keempat. Faktor pendekatan belajar yang meliputi kurang suka membaca buku, kesulitan membagi waktu, menunda-nunda pekerjaan, kurang berdiskusi dengan teman dan kurang bersungguh-sungguh. Kelima, faktor keluarga yang berupa, kurangnya motivasi dari keluarga, kurang dukungan finansial, dan tekanan agar cepat lulus. Keenam, faktor lingkungan teman, yang berupa; sama-sama malas mengerjakan skripsi, teman yang suka mengajak jalan-jalan, lingkungan kost yang tidak kondusif. Ketujuh, faktor administrasi skripsi yang berupa; lamanya mengurus surat dan perijinan, kendala 


\section{At-Taqaddum}

Vol. 11 No. 2 (2019) pp 186-233

DOI: http://dx.doi.org/10.21580/at.v11i2.4566

TOEFL dan IMKA, kendala upload dokumen dan jaringan yang sering eror. Kedelapan, referensi yang berupa kesulitan menemukan referensi, jumlahnya yang terbatas, dan tidak boleh dipinjam. i, faktor pembimbingan skripsi, yang berupa sulitnya menemui dosen, takut bertemu dosen, lamanya naskah dikoreksi, kurang mendapatkan masukan, dan perbedaan masukan pembimbing 1 dan 2, serta sulitnya memahmi masukan dari dosen. Kesepuluh, faktor aktifitas lain, yang berupa; kuliah sambil bekerja, sibuk dengan kegiatn organisasi kemahasiswaan dan kemasyarakatan, dan membantu orang tua di rumah.

\section{A. Pembahasan}

Sebagaimana temuan penelitian, faktor-faktor yang menghambat penyelesaian skripsi mahasiswa jurusan BPI ada sepuluh, yaitu; faktor kesehatan, faktor hambatan psikologis, faktor kemampuan akademik, faktor pendekatan belajar, faktor keluarga, faktor lingkungan/teman, faktor referensi, faktor adminsitrasi skripsi, faktor pembimbingan dosen, dan faktor kesibukan lain. Dari sembilan faktor tersebut, peneliti mengelompokkan menjadi dua, yaitu faktor internal, yang meliputi; kesehatan, hambatan psikologis, kemampuan akademik, dan pendekatan belajar. Sedangkan faktor ekstrinsik meliputi; keluarga, lingkungan/teman, referensi, pembimbingan dosen, dan kesibukan lain. Berikut uraiannya;

\section{Analisis Faktor Instrinsik}

Pertama, Faktor kesehatan. Berdasarkan hasil angket diperoleh data bahwa 4 dari 29 mahasiswa (13\%) mengaku bahwa masalah kesehatan menjadi salah satu kendala. Gangguan kesehatan tersebut berupa, kelelahan, kurang enak badan, dan pusing. Kelelahan terjadi karena selain kuliah, mahasiswa juga bekerja. Pekerjaan yang cukup menyita waktu (fulltime) dirasakan menguras energy sehingga mengalami kelelahan. 
Adanya masalah kesehatan yang menjadi salah satu kendala ini, sejalan dengan teori yang dikemukakan Muhibbin Syah di atas bahwa salah satu faktor yang mempengaruhi belajar adalah faktor kesehatan. Hal ini sejalan juga dengan pendapat Slameto yang menyebutkan bahwa faktor-faktor yang mempengaruhi hasil belajar banyak jenisnya, salah satunya faktor internal berupa kelelahan dan aspek jasmani. ${ }^{15} \mathrm{Hal}$ yang sama juga dikemukakan oleh Puwanto yang menyebutkan bahwa ada beberapa faktor yang mempengaruh proses dan hasil belajar. Faktor tersebut salah satunya adalah factor fisiologi yang berupa kondisi fisik dan panca inderanya. ${ }^{16}$

Hasil temuan ini, sejalan juga dengan penelitian yang dilakukan oleh Kusnendar tentang faktor-faktor yang menghambat penyelesaian studi, dimana salah satunya adalah faktor kelelahan mahasiswa. Hasil penelitiannya menunjukkan bahwa 40\% mahasiswa mengalami kelelahan dalam penyelesaian studi yang disebabkan juga karena faktor kesulitan membagi waktu dengan aktifitas yang lain. Kelelahan tersebut berupa kelelahan fisik dan juga psikhis. ${ }^{17}$

Meskipun hasil penelitian ini menunjukkan bahwa tidak banyak mahasiswa yang mengalami kendala terkait dengan faktor kesehatan, yaitu hanya 13\%, namun hal ini juga memperkuat hasil-hasil penelitian sebelumnya dan juga teori yang dikemukakan oleh beberapa ahli bahwa kesehatan menjadi salah satu faktor yang mempengaruhi keberhasilan studi, yang dalam penelitian ini masalah kesehatan tersebut menjadi kendala dalam penyelesaian skripsi.

15 Slameto. 2010. Belajar dan Faktor-faktor yang Mempengarubinya. Jakarta: Rineka Cipta. Hlm 54-70

${ }^{16}$ Ngalim Purwanto, Psikologi Pendidikan, (Bandung: Rosdakarya, 2003), hlm. 107.

${ }^{17}$ Febriyanto Kusnendar, Suwachid, dan Danar Susilo Wijayanto. 2012. Analisis Penghambat Penyelesaian Studi Mahasiswa S1 Program Studi Pendidikan Teknik Mesin Jurusan Pendidikan Teknik dan Kejuruan Fakultas keguruan dan Ilmu Pendidikan Universitas Sebelas Maret Surakarta 


\section{At-Taqaddum}

Vol. 11 No. 2 (2019) pp 186-233

DOI: http://dx.doi.org/10.21580/at.v11i2.4566

Kedua, Faktor hambatan psikologis. Berdasarkan angket diperoleh data bahwa 26 dari 29 mahasiswa mengaku bahwa hambatan psikologis menjadi salah satu kendala dalam penyelesaian skripsi. Artinya 89,6\% mahasiswa mengalami kendala hambatan psikologis yang berpengaruh terhadap penyelesaian skripsi, sedangkan sisanya sebesar 10,4\% mengaku bahwa hambatan psikologis tidak menjadi kendala dalam penyelesaian skripsinya.

Hambatan psikologis yang dimaksud berupa; kemalasan, kurangnya motivasi, menunda-nunda pekerjaan, stres, dan mengalami kecemasan. Kemalasan merupakan kondisi dimana seseorang mengalami keengganan melakukan sesuatu. Kemalasan merupakan salah satu bentuk respon psikologis seseorang terhadap sesuatu.

Selain kemalasan, problem lainnya berkenaan dengan motivasi. Suryabrata mendefinisikan motivasi sebagai keadaan yang terdapat dalam diri seseorang yang mendorongnya untuk melakukan aktivitas tertentu guna pencapaian suatu tujuan. ${ }^{18}$ Motivasi berfungsi untuk mendorong manusia untuk berbuat/bertindak, menentukan arah perbuatan, dan menyeleksi perbuatan individu. ${ }^{19}$

Berdasarkan pendapat tersebut, maka motivasi memiliki peran yang penting dalam mengarahkan perilaku individu. Dengan motivasi seseorang akan tergerak melakukan sesuatu. Seseorang yang memiliki motivasi tinggi maka akan memiliki keinginan yang kuat untuk melakukan sesuatu. Keinginan yang kuat tersebut akan memunculkan perilaku dalam mewujudkan keinginannya itu. Jika ditarik dalam persoalan penelitian ini, maka mahasiswa yang memiliki motivasi tinggi dalam menyelesaikan

\footnotetext{
${ }^{18}$ Sumadi Suryabrata, Psikologi Pendidikan, (Jakarta: Rajawali Press, 2004), hlm 70

${ }^{19}$ Ngalim Purwanto, Piskologi Pendidikan, (Bandung: Remaja Rosdakarya, 2008), hlm, 70-71
} 
skripsinya, cenderung akan melakukan upaya dan kerja keras untuk mewujudkan keinginannya tersebut yaitu penyelesaian skripsi. Sebaliknya mahasiswa yang memiliki motivasi yang rendah cenderung akan menarik diri dan tidak memiliki usaha untuk mewujudkan keinginannya.

Menurut Maslow, motivasi individu dipengaruhi juga oleh kebutuhan individu. Maslow mengemukakan adanya lima tingkatan kebutuhan dasar manusia, yaitu dari yang paling mendasar berupa kebutuhan fisiologis, dilanjutkan dengan kebutuhan rasa aman dan perlindungan, kebutuhan social, kebutuhan penghargaan, dan tingkatan yang paling tinggi adalah kebutuhan aktualisasi diri. Pemenuhan kebutuhan individu tersebut berbeda satu dengan lainnya. Hal ini dipengaruhi oleh banyak hal baik lingkungan fisik maupun lingkungan non-fisiknya.

Berpijak dari teori Maslow tersebut, maka munculnya motivasi mahasiswa dalam mengerjakan skripsi tersebut juga sangat dimungkinkan berkaitan dengan posisi kebutuhannya masing-masing. Apabila secara fisiologis, kebutuhannya belum terpenuhi, maka kebutuhan diatasnya bukan menjadi prioritas utamanya.

Hambatan psikologis lainnya yaitu menunda-nunda pekerjaan. Dalam psikologi, sikap tersebut disebut dengan prokrastinasi. Prokrastinasi merujuk pada sikap dan perilaku yang memiliki karakteristik mengulur atau memperpanjang waktu. Adapun prokrastinasi akademik sering diartikan sebagai perilaku menunda-nunda tugas akademik.

Menurut Ferrari (dalam Wulan dan Abdullah), prokarastinasi akademik memiliki beberap ciri, yaitu, pertama; penundaan untuk memulai ataupun menyelesaian tugas yang dihadapi; kedua, keterlambatan mengerjakan tugas; ketiga, kesenjangan waktu antara rencana dan kinerja actual; dan keempat, melakukan aktifitas lain yang lebih menyenangkan daripada menyelesaikan 


\section{At-Taqaddum}

Vol. 11 No. 2 (2019) pp 186-233

DOI: http://dx.doi.org/10.21580/at.v11i2.4566

tugas yang harus dilakukan. ${ }^{20}$ Lebih lanjut dijelaskan bahwa prokrastinasi disebabkan oleh faktor internal dan eksternal. Faktor internal berupa kondisi fisik dan kondisi psikis sedangkan faktor eksternal berupa kondisi lingkungan dan orang tua. ${ }^{21}$

Munculnya prokrastinasi akademik dalam mengerjakan skripsi diakui M-2 salah satu penyebabnya adalah lingkungan kos yang kurang mendukung. Hal ini sejalan dengan teori Ferrari yang menyebutkan bahwa penyebab prokrastinasi salah satunya adalah faktor eksternal yaitu, lingkungan fisik.

Ketiga, Faktor kemampuan akademik. Berdasarkan angket diperoleh data bahwa 21 dari 29 mahasiswa mengaku bahwa kemampuan akademik menjadi salah satu kendala dalam penyelesaian skripsi. Artinya 72,4\% mahasiswa mengalami kendala kemampuan akademik yang berpengaruh terhadap penyelesaian skripsi, sedangkan sisanya sebesar $27,6 \%$ mengaku bahwa kemampuan akademik tidak menjadi kendala dalam penyelesaian skripsinya.

Kemampuan akademik yang dimaksud berupa; kesulitan mengelaborasi masalah penelitian, keterbatasan penguasaan metodologi penelitian, kemampuan menulis yang terbatas, kesulitan menuangkan gagasan/menganalisis, kendala penguasaan Bahasa asing, dan minimnya kemampuan membaca al quran.

Kendala mengelaborasi masalah penelitian ditandai dengan sulitnya mahasiswa dalam memahami permasalahan penelitian yang sedang dilakukan, kesulitan melihat kesenjangan atara idealitas dan realitas, serta kesulitan dan menyusun latar belakang masalah. Masalah penelitian menjadi salah satu persoalan mendasar dalam sebuah penelitian. Pada umumnya mahasiswa

${ }^{20}$ Dyah Ayu Nur Wulan dan Sri Muliati Abdullah. Prokrastinasi Akademik dalam Penyelesaian Skripsi. Dalam Jurnal Sosio-Humanira. Vol 5. No. 1 Mei 2014. Hlm 1011

${ }^{21}$ Ibid. Hlm. 11-12. 
mengangkat judul penelitian bukan berbasis pada persoalan, namun karena pertimbangan lokasi dan kecenderungan juduljudul yang sudah ada. Demikian halnya dengan elaborasi latar belakang yang belum komprehensif. Pada umumnya persoalan elaborasi latar belakang ini banyak dijumpai pada saat bimbingan proposal. Seringkali belum ditemukan kesenjangan antara idealitas dan realitas dalam latar belakang, serta minimnya data-data pendukung awal yang diperlukan sebagai bahan kajian tentang pentingnya penelitian tersebut untuk dilakukan.

Kendala lain yang berkaitan dengan kemampuan akademik adalah penguasaan metodologi penelitian yang terbatas. Hal ini dilihat dari ketidaksesuaian antara judul rumusan masalah dan teori, ketidaktepatan dalam menentukan sumber data, tidak paham tentang keabsahan data dan analisis data, serta implementasi dari metode penelitian di Bab I dengan pembahasan pada bab III dan IV.

Temuan penelitian ini sejalan dengan penelitian yang dilakukan oleh Sefna Rismen yang mengungkapkan bahwa; pertama, sebesar 66,67\% mahasiswa mengalami kesulitan dalam penyiapan judul penelitian yang menunjukkan bahwa rendahnya kemampuan nalar dan menulis siswa sehingga kesulitan menuangkan ide dalam bentuk tulisan. Kedua, sebesar 51,28\%, mahasiswa kesulitan membuat latar belakang masalah. Mahasiswa mengalami kesulitan dalam menuangkan ide dan gagasannya dalam bentuk tulisan, kebanyakan mereka lebih buka melakukan copy paste dari tulisan yang ada, sehingga memunculkan budaya malas berfikir. ${ }^{22}$

Penelitian lain yang terkait dengan kemampuan akademik yang menjadi kendala dalam penyusunan skripsi dilakukan juga

${ }^{22}$ Sefna Rismen, Analisis Kesulitan Mahasiswa dalam Penyelesaian Skripsi di Prodi Pendidikan Matematika STKIP PGRI Sumbar, dalam Jurnal LEMMA, Vol. 1 No, 2. Mei 2015. pp. 57-62 


\section{At-Taqaddum}

Vol. 11 No. 2 (2019) pp 186-233

DOI: http://dx.doi.org/10.21580/at.v11i2.4566

oleh Wiyatmo, dkk. Hasil penelitiannya menunjukkan bahwa persentase kendala-kendala yang berkaitan dengan penguasaan metode penelitian dalam penulisan skripsi yaitu; Kesulitan dalam membuat desain penelitian dialami oleh $61,8 \%$ mahasiswa. Kesulitan dalam menyusun instrument penelitian juga dialami oleh sebagian besar mahasiswa $(67,7 \%)$. Kesulitan dalam teknik pengumpulan data dialami oleh $58,9 \%$ mahasiswa. Kesulitan dalam menginterpretasi hasil penelitian dialami oleh 47\% mahasiswa. Kesulitan dalam menyajikan hasil penelitian dirasakan oleh 44\% mahasiswa. Kesulitan dalam menganalisis hasil penelitian disarakan oleh 61,8\% mahasiswa. Kesulitan dalam menentukan statistik persyaratan uji hipotesis dirasakan oleh 67,7\% mahasiswa. Kesulitan dalam pengujian hipotesis, kesulian dalam menyajikan hasil penelitian dalam bentuk grafik/gambar/ diagram, dan menginterpretasi grafik/gambar/diagram, dan kesulitan dalam membuat pembahasan hasil penelitian secara berturutan dirasakan oleh $58,9 \% ; 41,2 \% ; 47,1 \%$; dan $50 \%$ mahasiswa. ${ }^{23}$

Berdasarkan hasil penelitian Wiyatmo dkk tersebut dapat dilihat bahwa kesulitan dalam metodologi penelitian menunukkan persentase yang cukup tinggi. Apabila dihubungkan dengan temuan penelitian ini, maka kemampuan akademik yang terkait dengan penguasaan MP merupakan salah satu kendala yang dihadapi mahasiswa. Berdasarkan kurikulum 2010 (yang berlaku bagi mahasiswa angkatan 2010 sampai dengan 2014), terdapat dua mata kulih khusus yang mengajarkan tentang Metodologi Penelitian, yaitu Metodologi penelitian (2SKS), dan Metodologi penelitian BP (2 SKS). Dengan empat SKS tersebut, idealnya cukup membekali mahasiswa tentang penguasan MP, namun pada

23 Yusman Wiyatmo, Mundilarto, Suharyanto, dan Eko Widodo, Efektivitas Bimbingan Tugas Akbir Skripsi (Tas) Mahasiswa Jurusan Pendidikan Fisika FMIPA UNY, dalam Prosiding Seminar Nasional Penelitian, Pendidikan dan Penerapan MIPA, Fakultas MIPA, Universitas Negeri Yogyakarta, 15 Mei 2010 
kenyataannya tidak semua mahasiswa memiliki penguasaan MP yang baik.

Kendala lainnya berkaitan dengan kemampuan menulis yang terbatas. Temuan penelitian menunjukkan bahwa mahasiswa terkendala dengan kemampuan menulis yang minim tersebut ditandai dengan kesulitan dalam menyusun kalimat, paragraph, menuangkan pokok-pokok pikiran menjadi sebuah paragaraf, kesulitan dalam menuangkan gagasan dalam bentuk tulisan, serta banyaknya kesalahan dalam tata tulis seperti kesalahan dalam penggunaan tanda baca, kata penghubung, kata depan, awalan dan akhiran, penulisan innote/footnote, serta penulisan kutipan langsung dan tidak langsung. Penguasaan kemampuan ini penting mengingat skripsi merupakan bentuk penuangan gagasan dan ide dalm bentuk tulisan. Karenanya penguasaan terhadap kemampuan ini menjadi salah satu prasyarat penting dalam mengerjakan skripsi.

Kendala dalam kemampuan akademik lainnya yaitu tentang penguasaan Bahasa asing. Universitas Islam Negeri Walisongo Semarang menerapkan kebijakan bahwa mahasiswa harus memiliki skore TOEFL 400 (Bahasa Inggris) dan skore IMKA 300 (Bahasa Arab) pada saat mendaftar ujian akhir. ${ }^{24}$ Sebagian mahasiswa mengalami kendala terkait dengan persyaratan tersebut. Banyak diantaranya yang harus menempuh ujian sampai 5 atau 6 kali. Hal ini dapat dimaklumi mengingat input mahsiswa UIN yang sangat beragam. Kebijakan ini disatu sisi dilakukan dalam rangka untuk pemenuhan standar lulusan S1, namun disisi yang lain juga menjadi kendala dalam penyelesaian studi.

\footnotetext{
${ }^{24}$ Kebijkan dan ketentuan tentang TOEFL dan IMKA ini pada awalnya diterapkan pada saat mahasiswa mendaftar ujian komprehensif, sejak tahun 2017 kewajiban untuk lulus dengan skor tersebut diberlakukan pada saat mendaftar ujian munaqasah. Kebijakan tersebut berlakubagi mahasiswa 2012 tahun dan seterusnya.
} 


\section{At-Taqaddum}

Vol. 11 No. 2 (2019) pp 186-233

DOI: http://dx.doi.org/10.21580/at.v11i2.4566

Minimnya kemampuan baca tulis al Quran juga menjadi kendala dalam penyelesaian skripsi. Hal tersebut dialami R-13 yang kemampuan membaca dan menulis al Quran masih minim. Di sisi lain, dosen pembimbing memiliki standar khusus bagi mahasiswa yang bimbingan harus bisa membaca al Quran. Karena itu, proses bimbingan belum bisa dilakukan apabila mahasiswa yang bersangkutan belum bisa memenuhi standarisasi tersebut. Dilihat dari persolan tersebut, sesungguhnya kemampuan baca tulis al Quran merupakan kemampuan dasar yang seharusnya dimiliki mahasiswa. Apalagi UIN Walisongo merupakan institusi pendidikan tinggi keagamaan yang tentu saja berbasis pada penguasaan ilmu-ilmu keagamaan dan juga umum. Proses seleksi awal bagi mahasiswa baru, diduga menjadi penyebab beragamnya kemampuan mahasiswa yang masuk, salah satunya terkait dengan kemampuan baca tulis al Quran.

Keempat, Faktor Pendekatan Belajar. Berdasarkan angket diperoleh data bahwa 22 dari 29 mahasiswa mengaku bahwa pendekatan belajar menjadi salah satu kendala dalam penyelesaian skripsi. Artinya 75,9\% mahasiswa mengalami kendala dalam hal pendekatan belajar yang berpengaruh terhadap penyelesaian skripsi, sedangkan sisanya sebesar $24,1 \%$ mengaku bahwa pendekatan belajar tidak menjadi kendala dalam penyelesaian skripsinya.

Kendala pendekatan belajar yang dimaksud berupa; minat baca yang rendah, kesulitan membagi waktu, kurangnya teman untuk berdiskusi, dan kurangnya kesungguhan dalam mengerjakan skripsi. Pendekatan belajar sangat terkait dengan sikap dan kebiasaan belajar.

Allport seperti dikutip Gable mengemukakan bahwa sikap adalah sesuatu kesiapan mental dan saraf yang tersusun melalui pengalaman dan memberikan pengaruh langsung kepada respon indidividu terhadap semua obyek atau situasi yang berhubungan 
dengan obyek itu. ${ }^{25}$ Harlen mengemukakan bahwa sikap merupakan kesiapan atau kecenderungan seseorang untuk bertindak dalam menghadapi suatu obyek atau situasi tertentu. ${ }^{26}$

Sikap belajar berperan dalam menentukan aktivitas belajar individu. Sikap belajar yang positif berkaitan erat dengan minat dan motivasi. Oleh karena itu, apabila faktor lainnya sama, individu yang sikap belajarnya positif akan belajar lebih aktif dan dengan demikian akan memperoleh hasil yang lebih baik dibandingkan individu yang sikap belajarnya negatif. ${ }^{27}$ Berdasarkan teori tersebut dapat dipahami bahwa mahasiswa yang memiliki sikap yang positif dalam tugas akademiknya akan memiliki peluang untuk menyelesaian skripsi dengan baik, dan sebaliknya sikap negative akan menjadikan mahasiswa mengalmi kendala dalam penyelesaian skripsinya.

Kebiasaan membaca, dan kesungguhan dalam melakukan sesuatu berkaitan dengan kebiasaan belajar. Berbagai hasil penelitian menunjukkan bahwa hasil belajar mempunyai korelasi positif dengan kebiasaan belajar atau study habit. Witherington dalam Andi Mappiare 1983 mengartikan kebiasaan (habit) sebagai: An acquired way of acting which is persistent, uniform, and fairly automatic (Kebiasaan merupakan cara bertindak yang diperoleh melalui belajar secara berulang-ulang, yang pada akhirnya menjadi menetap dan bersifat otomatis). ${ }^{28}$

Perbuatan kebiasaan tidak memerlukan konsentrasi perhatian dan pikiran dalam melakukannya. Kebiasaan dapat berjalan terus, sementara individu memikirkan atau memerhatikan hal-hal lain. Kebiasaan belajar dapat diartikan sebagai cara atau teknik yang menetap pada diri siswa pada waktu menerima

\footnotetext{
${ }^{25}$ Robert K. Gable, Instrumen Development in Affective Domain (Boston: Kluwer).

26 Wyne Harlen, Teacbing and Learning Primary Science (London: Row Publisher, 1985), pp.44-45

${ }^{27}$ Djaali, pp. 117

${ }^{28}$ Andi Mappiare, Psikologi Orang Dewasa (Surabaya: Usaha Nasional, 1983), pp. 34.
} 


\section{At-Taqaddum}

Vol. 11 No. 2 (2019) pp 186-233

DOI: http://dx.doi.org/10.21580/at.v11i2.4566

pelajaran, membaca buku, mengerjakan tugas, dan pengaturan waktu untuk menyelesaikan kegiatan. Kebiasaan belajar dibagi ke dalam dua bagian, yaitu Delay Avoidan (DA) dan Work Methods (WM). DA menunjuk pada ketepatan waktu penyelesaian tugastugas akademis, menghindarkan diri dari hal-hal yang memungkinkan tertundanya penyelesaian tugas, dan menghilangkan rangsangan yang akan mengganggu konsentrasi dalam belajar. Adapun WM menunjuk kepada penggunaan cara (prosedur) belajar yang efektif, dan efisiensi dalam mengerjakan tugas akademik dan keterampilan belajar. ${ }^{29}$

Berdasarkan pendapat Djaali tersebut, maka mahasiswa yang memiliki kebiasaan belajar yang baik akan memiliki cara atau teknik yang tepat dalam proses studinya, seperti membaca buku, mampu mengerjakan tugas dengan baik, dan kemampuan untuk mengatur waktu untuk menyelesaikan tugas akademik, salah satunya skripsi.

\section{Analisis Faktor Ekstrinsik}

Pertama, Faktor Keluarga. Berdasarkan angket diperoleh data bahwa 10 dari 29 mahasiswa mengaku bahwa faktor keluarga menjadi salah satu kendala dalam penyelesaian skripsi. Artinya $34.5 \%$ mahasiswa beranggapan bahwa faktor keluarga berpengaruh terhadap penyelesaian skripsi, sedangkan sisanya sebesar $65.5 \%$ mengaku bahwa faktor keluarga tidak menjadi kendala dalam penyelesaian skripsinya.

Faktor keluarga tersebut berupa, kurangnya motivasi orang tua, kurang dukungan finansial dari orang tua, serta tekanan dari orang tua agar segera lulus. Kurangnya motivasi dari orang tua tersebut ditandai dengan minimnya perhatian dari orang tua tentang persoalan-persoalan yang dihadapi mahasiswa dalam menyelesaikan skripsinya. Selain itu, orang tua juga tidak tahu

${ }^{29}$ Djaali, pp. 128. 
menahu tentang proses atau tahapan yang harus dilalui mahasiswa dalam menyusun skripsi.

Kurangnya motivasi atau dukungan psikologis dari orang tua menjadikan individu tersebut kurang bersemangat dalam melakukan sesuatu. sebagaimana diketahui bahwa motivasi dibagi menjadi dua, yaitu motivasi intrinsic dan motivasi ekstrinsik. Motivasi intrinsic merupakn motivasi yang tumbuh dari dalam individu itu sendiri, sedangkan motivasi ekstrinsik adalah motivasi yang dipengaruhi pihak luar. Sekalipun motivasi ekstrinsik sifanya hanya penunjang namun keberadaannya juga diperlukan untuk memperkuat perilaku individu. Tanpa dukungan dan motivasi dari orang tua maka dapat dimungkinkan menurunkan semangat individu dalam hal ini mahasiswa untuk menyelesaiakn skripsi dan studinya. Hal ini juga berlaku sebaliknya, motivasi eksternal dimungkinkan akan memperkuat semangat mahasiswa dalam proses studinya.

Selain kurangnya dukungan motivasi, dukungan finansial juga diperlukan. Sebagaimana diketahui bahwa dalam proses penyelesaian skripsi mahasiswa memerlukan dana lebih untuk keperluan referensi, cetak, fotokopi dan lain-lain. Apabila secara finansial dukungan finansial itu kurang, maka mahasiswa berusaha untuk mencukupinya dengan bekerja. Kuliah sambil bekerja itulah yang kemudian secara langsung berefek pada kemampuan untuk membagi waktu, fikiran, dan tenaga mahasiswa. Apabila yang bersangkutan tidak mampu mengelolanya dengan baik, sangat dimungkinkan proses penyelesaian skripsi menjadi terganggu.

Pada sisi yang lain, tuntutan dari orang tua agar mahasiswa segera menyelesaikan skripsinya juga mempengaruhi psikologi mahasiswa tersebut. Tuntutan yang tanpa diikuti dengan support atau dukungan positif justru kontraproduktif, sehingga tidak mempercepat dan sangat dimungkinkan akan menambah beban psikologis yang berdampak pada terkendalanya skripsi. 


\section{At-Taqaddum}

Vol. 11 No. 2 (2019) pp 186-233

DOI: http://dx.doi.org/10.21580/at.v11i2.4566

Secara umum, kendala dari faktor keluarga ini, sejalan dengan penelitian yang dilakukan oleh Kusnendar, dkk yang menunjukkan bahwa keluarga merupakan salah satu faktor yang mempengaruhi penyelesaian studi mahasiswa dengan persentase sebesar $67,5 \%$. Artinya 67,5\% mahasiswa menyatakan keluarga merupakan salah satu yang menjadi kendala dalam penyelesaian studi. Faktor keluarga tersebut berupa; keluarga kurang memberikan dukungan motivasi, kurang memberikan dukungan finansial, dan fasilitas belajar. ${ }^{30}$

Hasil penelitian tersebut juga sejalan dengan pendapat Slameto yang menyebutkan bahwa faktor-faktor yang mempengaruhi hasil belajar banyak jenisnya, tetapi dapat digolongkan menjadi dua golongan yaitu saja, yaitu factor intern dan faktor ekstern. Salah satu faktor eksternal berupa lingkungan keluarga. ${ }^{31}$

Kedua, Faktor lingkungan/teman. Berdasarkan angket diperoleh data bahwa 11 dari 29 mahasiswa mengaku bahwa faktor lingkungan/teman menjadi salah satu kendala dalam penyelesaian skripsi. Artinya 37,9\% mahasiswa beranggapan bahwa faktor lingkungan/teman berpengaruh terhadap penyelesaian skripsi, sedangkan sisanya sebesar $62,1 \% \%$ mengaku bahwa faktor lingkungan/teman tidak menjadi kendala dalam penyelesaian skripsinya.

Lingkungan tempat tinggal dan teman yang menjadi kendala dan hambtan tersebut berupa; situasi kost yang ramai, tidak kondusif untuk mengerjakan skripsi, teman yang sering mengajak

${ }^{30}$ Febriyanto Kusnendar, Suwachid, dan Danar Susilo Wijayanto. 2012. Analisis Penghambat Penyelesaian Studi Mahasiswa S1 Program Studi Pendidikan Teknik. Mesin Jurusan Pendidikan Teknik dan Kejuruan Fakultas keguruan dan Ilmu Pendidikan Universitas Sebelas Maret Surakarta. Hasil Penelitian.

31 Slameto. 2010. Belajar dan Faktor-faktor yang Mempengarubinya. Jakarta: Rineka Cipta. pp 54-70 
jalan (melakukan aktifitas yang kurang penting), dan teman yang sama-sama malas mengerjakan skripsi.

Lingkungan merupakan kondisi disekitar individu yang secara langsung atau tidak langsung berinteraksi dengan individu. Lingkungan terbagi dua yaitu lingkungan fisik dan lingkungan non fisik. Lingkungan fisik dapat berupa gedung, bangunan, sarana prasarana, dan lingkungan alam lainnya. Sedangkan lingkungan non-fisik berupa teman dan atau orang-orang yang berinteraksi dengan individu dalam kesehariannya.

Dalam penelitian ini, yang mempengaruhi proses penyelesaian skripsi lebih mengarah pada lingkungan non-fisik, khususnya teman kos dan teman kuliah. Situasi kos yang ramai dan tidak kondusif menjadi salah satu penyebabnya. Dengan adanya situasi yang ramai secara tidak langsung akan berdampak pada kurangnya konsentrasi. Pada kasus yang lain, keinginan untuk bersenangsenang dengan melakukan kegiatan-kegiatan yang sebenarnya kurang penting seperti jalan-jalan, 'ngobrol', dan 'kumpul-kumpul bareng teman' juga menjadi penyebabnya. Selain itu, lingkungan teman yang sama-sama mengalami kemalasan dalam mengerjakan skripsi juga dirasakan sebagai pemicu untuk menunda-nunda.

Secara umum, lingkungan merupakan salah satu faktor eksternal yang mempengaruhi proses belajar. Sebagaimana hasil penelitian yang dilakukan Kusnendar menyatakan bahwa ada dua faktor penghambat penyelesaian studi mahasiswa yaitu faktor internal dan eksternal. Salah satu faktor eksternal tersebut adalah teman bergaul. Pengaruh faktor teman bergaul tersebut sebesar 67,5\%. Artinya 67,5\% mahasiswa beranggapan bahwa teman bergaul yang tidak sesuai menjadikan kendala dalam penyelesaian studi. Adapun teman yang diharapkan menunjang dalam penyelesaian studi yaitu teman yang bisa memotivasi, membantu 


\section{At-Taqaddum}

Vol. 11 No. 2 (2019) pp 186-233

DOI: http://dx.doi.org/10.21580/at.v11i2.4566

kesulitan jika mengalami masalah, dan bisa diajak diskusi tentang skripsi yang sedang dikerjakan. ${ }^{32}$

Hal ini juga sejalan dengan teori yang dikemukakan oleh Ngalim Purwanto dan juga Slameto yang mengemukakan bahwa faktor-faktor yang mempengaruhi belajar salah satunya adalah lingkungan. Lingkungan tersebut dapat berupa lingkungan pendidikan, maupun lingkungan sosial (teman). ${ }^{33}$

Ketiga, Faktor administrasi skripsi. Berdasarkan angket diperoleh data bahwa 17 dari 29 mahasiswa mengaku bahwa sistem administrasi skripsi menjadi salah satu kendala dalam penyelesaian skripsi. Artinya 58,6\% mahasiswa mengalami kendala dalam sistem adminstrasi skripsi yang berpengaruh terhadap penyelesaian skripsi, sedangkan sisanya sebesar 41,4\% mengaku bahwa sistem administrasi skripsi tidak menjadi kendala dalam penyelesaian skripsinya.

Kendala yang berkaitan dengan sistem adminstrasi skripsi tersebut berupa; proses perijinan dan surat menyurat yang lama, berkas persyaratan untuk ujian yang banyak, upload dokumen ujian yang sulit karena jaringan yang sering eror, sistem yang tidak terintegrasi antara fakultas dan pusat bahasa, dan masalah syarat TOEFL_IMKA.

Proses penyusunan dan penyelesaian skripsi tidak bisa dilepaskan dari sistem adimintrasinya. Pengelolaan sistem administrasi yang baik dan profesional akan mendukung dalam tahapan penyelesaian skripsi, dan sebaliknya sistem administrasi yang kurang baik, dapat menjadi kendala. Menurut S. Pamudji

${ }^{32}$ Febriyanto Kusnendar, Suwachid, dan Danar Susilo Wijayanto. 2012. Analisis Penghambat Penyelesaian Studi Mahasiswa S1 Program Studi Pendidikan Teknik Mesin Jurusan Pendidikan Teknik dan Kejuruan Fakultas keguruan dan Ilmu Pendidikan Universitas Sebelas Maret Surakarta.

${ }^{33}$ Ngalim Purwanto, Psikologi Pendidikan, (Bandung: Rosdakarya, 2003), hlm. 107. Baca juga Slameto. 2010. Belajar dan Faktor-faktor yang Mempengarubinya. Jakarta: Rineka Cipta. pp 54-70 
(dalam Siswanto), sistem merupakan organisasi unsur-unsur yang kompleks tetapi utuh (komprehensif) yang berproses dan bersinergi untuk mencapai tujuan secara efektif (berhasilguna) dan efisien (berdaya guna). Unsur-unsur yang ada dalam sebuah sistem dapat terdiri dari sumber daya manusia, peralatan, bahan, prosedur, dan lain-lain.

Dalam sistem pengelolaan dan layanan pengerjaan skripsi sumber daya manusia yang terlibat terdiri dari dosen, karyawan, dan mahasiswa. Dosen, karyawan, dan mahasiswa yang terlibat memiliki peran dan tugas masing-masing dalam rangka pencapaian tujuan pengerjaan tugas akhir skripsi. Sementara bahan dan peralatan yang dipergunakan dalam sistem pengelolaan dan layanan pengerjaan tugas akhir skripsi juga memiliki peran yang penting dalam mencapai tujuan. Salah satu peralatan yang dapat membantu dalam pengelolaan dan layanan pengerjaan tugas akhir skripsi adalah media yang dapat dipergunakan untuk memberikan informasi mengenai judul-judul skripsi yang sudah pernah diteliti, media publikasi hasil penelitian, dan lain-lain.

Berdasarkan pendapat Hamid tersebut, maka salah satu problem yang dialami mahasiswa adalah terkait dengan media yang digunakan dalam pengelolaan skripsi. Media tersebut berperan sebagai alat bantu yang bertujuan untuk mempermudah proses, yang dalam hal ini pendaftaran ujian online. Namun kendala yang dialami justru pada saat media tersebut tidak dapat berfungsi sehingga perannya menjadi kontraproduktif. Seharusnya system untuk mempermudah, namun justru yang terjadi sebaliknya.

Menurut Hamid (dalam Siswanto), agar sistem yang ada dapat membantu mempercepat dalam penyelesaian suatu pekerjaan maka dalam pengelolaan sebuah sistem harus ada: (1) perencanaan yang didasarkan pada analisis kebutuhan, analisis tujuan, analisis masalah, dan analisis pemecahan masalah, (2) 


\section{At-Taqaddum}

Vol. 11 No. 2 (2019) pp 186-233

DOI: http://dx.doi.org/10.21580/at.v11i2.4566

implementasi yang memunculkan adanya hambatan dan tantangan, (3) evaluasi yang menghasilkan kebijakan, serta (4) revisi yang menelorkan rekomendasi untuk memodifikasi atau memperbaiki perencanaan semula. ${ }^{34}$

Selain sistem pengelolaan dan layanan pengerjaan skripsi, unsur lain yang berpengaruh terhadap proses pengerjaan skripsi adalah prosedur pengerjaan skripsi. Prosedur dalam pengerjaan tugas akhir skripsi dapat dikelompokkan dalam 3 bagian. Bagianbagian tersebut ialah pengajuan judul, proses pengerjaan, dan ujian skripsi. Kendala yang dialami mahasiswa berkenaan dengan proses pengerjaan dan ujian skripsi. Proses pengerjaan terkait dengan perijinan yang cukup lama, dan surat-menyurat. Sedangkan ujian skripsi terkendala dengan persyaratan yang beragam, dan kesulitan upload data.

Keempat, Faktor Referensi. Berdasarkan angket diperoleh data bahwa 17 dari 29 mahasiswa mengaku bahwa faktor referensi menjadi salah satu kendala dalam penyelesaian skripsi. Artinya 58,6\% mahasiswa mengalami kendala dalam referensi yang berpengaruh terhadap penyelesaian skripsi, sedangkan sisanya sebesar 41,4\% mengaku bahwa referensi tidak menjadi kendala dalam penyelesaian skripsinya.

Berdasarkan temuan penelitian, ketersediaan referensi yang dapat dijadikan rujukan penelitian di lingkungan UIN walisongo ditambah lagi dengan perpustakaan wilayah dirasakan cukup memadai. Kendala dijumpai hanya pada tema-tema tertentu yang memang referensi tersebut tidak dijual secara bebas, misalnya terkait dengan bimbingan di LAPAS, Rumah Sakit dan lainnya. Adapun tema-tema umum tentang studi kefakultasan dan kejurusanan dipandang cukup memadai.

\footnotetext{
${ }^{34}$ Ibnu Siswanto dan Yoga Guntur Sampurno, Faktor-faktor Penghambat Penyelesaian Tugas Akhir Skripsi Mahasiswa Pendidikan Teknik Otomotif FT UNY. Yogyakarta: Universitas Negeri Yogyakarta.
} 
Referensi merupakan salah satu kunci dalam penyusunan kerangka teori penelitian. Tanpa adanya referensi yang memadai sangat tidak mungkin akan menghasilkan penelitian yang berkualitas. Ketersediaan referensi di perpustakaan kampus menjadi kebutuhan primer bagi mahasiswa yang menyusun skripsi.

Namun pada kenyataannya, tidak semua literature yang dibutuhkan tersedia di perpustakaan kampus. Dalam kondisi seperti ini, akan menjadi kendala tersendiri bagi mahasiswa. Persoalan tentang hambatan yang terkait dengan referensi ini juga senada dengan penelitian yang dilakukan oleh Sefna Rismen yang menunjukkan bahwa faktor kesulitan mencari referensi merupakan salah satu faktor yang menjadi kendala mahasiswa dalam tahapan proses penyiapan judul skripsi. Hal ini menjadi faktor dominan ketiga yang memiliki persentase sebesar 41,03\%. Penelitian yang dilakukan oleh Wiyatmo, dkk juga mengemukakan bahwa faktor kesulitan referensi menjadi salah satu kendala dalam penyelesaian tugas akhir mahasiswa, selain faktor-faktor penghambat lainnya. ${ }^{35}$

Berdasarkan penelitian ini, dan juga didukung oleh hasil-hasil penelitian lainnya menunjukkan bahwa ketersediaan referensi menjadi salah satu kebutuhan dasar bagai mahasiswa yang sedang menyelesaikan skripsi.

Kelima, Faktor Bimbingan dosen. Berdasarkan angket diperoleh data bahwa 18 dari 29 mahasiswa mengaku bahwa faktor bimbingan dosen menjadi salah satu kendala dalam penyelesaian skripsi. Artinya 62,1\% mahasiswa mengalami kendala dalam hal pembimbingan dengan dosen yang

35 Yusman Wiyatmo, Mundilarto, Suharyanto, dan Eko Widodo, Efektivitas Bimbingan Tugas Akbir Skripsi (Tas) Mahasiswa Jurusan Pendidikan Fisika FMIPA UNY, dalam Prosiding Seminar Nasional Penelitian, Pendidikan dan Penerapan MIPA, Fakultas MIPA, Universitas Negeri Yogyakarta, 15 Mei 2010 


\section{At-Taqaddum}

Vol. 11 No. 2 (2019) pp 186-233

DOI: http://dx.doi.org/10.21580/at.v11i2.4566

berpengaruh terhadap penyelesaian skripsi, sedangkan sisanya sebesar 37,9\% mengaku bahwa proses pembimbingan tidak menjadi kendala dalam penyelesaian skripsinya.

Kendala yang berkaitan dengan faktor pembimbingan dosen, berupa: lamanya proses bimbingan, 'takut' menemui dosen, dosen memiliki kesibukan yang beragam, dosen sulit ditemui, keterbatasan waktu bimbingan, perbedaan pendapat antara pembimbing 1 dan 2, kurang masukan dosen, serta tidak bisa memahami masukan dari dosen.

Jika dilihat dari sudut pandang sistem pengelolaan dan layanan pengerjaan skripsi, unsur lain yang berpengaruh terhadap proses pengerjaan skripsi adalah prosedur pengerjaan skripsi. Prosedur dalam pengerjaan tugas akhir skripsi dapat dikelompokkan dalam 3 bagian. Bagian-bagian tersebut ialah pengajuan judul, proses pengerjaan, dan ujian skripsi. Proses pembimbingan dosen masuk pada tahapan proses pengerjaan. Dalam proses ini, mahasiswa melakukan konsultasi dengan dosen pembimbing yang telah ditunjuk oleh program studi/jurusan.

Sesuai dengan buku panduan skripsi pada Fakultas Dakwah dan Komunikasi, proses penulisan skripsi memiliki prosedur sebagai berikut: 1) Penulisan skripsi di bawah arahan pembimbing yang ditunjuk, 2) Berdasarkan proposal penelitian yang telah disetujui oleh pembimbing, diujikan dalam ujian komprehensif, telah direvisi dan telah disetujui oleh para penguji, mahasiswa melakukan langkah-langkah penelitian dan penulisan skripsi sampai selesai di bawah bimbingan dosen, 3) Dalam proses bimbingan, mahasiswa dapat bertemu dan berkonsultasi dengan dosen pembimbing sesuai dengan kesepakatan waktu dan tempat dalam suasana saling menghormati dan mengarahkan untuk tujuan akademik, 4) Skripsi yang telah selesai dan disetujui oleh pembimbing, dapat didaftarkan untuk mengikuti ujian munaqasah.

Point-point tersebut masih bersifat umum, belum ada aturan spesifik yang membahas tentang bagaimana masing-masing tahap 
tersebut dilakukan. Secara umum, implementasi proses penulisan skripsi yang dilakukan mahasiswa sudah memenuhi aturan sebagaimana yang diatur pada point-point di atas.

Berkaitan dengan pembimbing, dalam buku panduan skripsi disebutkan tentang tujuan pembimbing, yaitu: 1) Memberikan pertimbangan, mengoreksi, dan menyetujui topic/ judul, kerangka umum, dan usulan skripsi. 2) Memberikan masukan dan arahan dalam langkah-langkah proses penelitian. 3) Memberikan masukan dan arahan dalam proses penelitian dan penyusunan skripsi. 4) Memberikan petunjuk praktis tentang metodologi penelitian serta teknik penulisan skripsi. 5) Memberikan koreksi terhadap draf naskah proposal. 6) Memberikan koreksi terhadap draf naskah awal skripsi. 7) Memberikan persetujuan terhadap draf akhir skripsi. 8) Memberikan nilai bimbingan yang merupakan bagian dari nilai skripsi.

Berdasarkan tugas pembimbing tersebut dapat dipahami bahwa pembimbing memiliki tugas untuk memberikan masukan, arahan, dan koreksi terhadap naskah skripsi mahasiswa mulai dari tahapan pengajuan proposal sampai dengan tahap penyusunan akhir skripsi. Secara umum tugas tersebut sudah dilakukan oleh pembimbing sebagaimana yang ada dalam pansuan tersebut. Hanya saja panduan tersebut tidak mengatur secara spesifik tentang standar ataupun batasan dalam proses bimbingan. Persoalan yang muncul berkaitan dengan kesulitan dalam bertemu pembimbing, dan lamanya naskah dikoreksi belum di atur dalam ketentuan tersebut.

Adapun tentang proses pembimbingan diatur sebagai berikut: 1) Proses pembimbingan dilakukan secara teratur dalam batas waktu maksimal satu tahun terhitung sejak penunjukannya oleh Dekan. Apabila dalam waktu satu tahun belum dapat menyelesaikan penulisan skripsi, maka Dekan memperpanjang setiap satu semester sampai batas akhir masa studi. 2) Bila terjadi perbedaan pendapat yang tidak dapat dipertemukan antara pembimbing dan mahasiswa atau antara 


\section{At-Taqaddum}

Vol. 11 No. 2 (2019) pp 186-233

DOI: http://dx.doi.org/10.21580/at.v11i2.4566

pembimbing satu dengan pembimbing yang lain, maka Ketua Jurusan/Program Studi dan atau Dekan atas pengaduan salah satu pihak yang terkait melakukan pendekatan untuk menyelesaikan perbedaan tersebut berdasarkan prinsip-prinsip ilmiah dan ukhuwah. 3) Jika perbedaan tersebut tidak dapat terselesaikan, Dekan atas rekomendasi dari Ketua Jurusan/Program Studi dapat membatalkan tugas pembimbingan dan menunjuk pembimbing yang baru.

Berdasarkan aturan tersebut dijelaskan tentang batas waktu penyelesaian skripsi yaitu satu tahun dan dapat diperpanjang kembali. Dalam pelaksanaannya, pada saat pembimbingan tersebut melebihi satu tahun secara otomatis tetap dilanjutkan tanpa adanya pembaruan/perpanjangan kontrak bimbingan tersebut. Pada point yang kedua, terjadinya perbedaan pendapat antara pembimbing 1 dan 2 selama ini belum sampai pada proses penggantian pembimbimbing baru. Pada beberapa kasus ada pergantian pembimbing disebabakan oleh pertimbangan akademik dan personal.

Secara spesisfik, belum ada aturan yang membahas tentang hak dan kewajiban yang ahrus dipenuhi oleh mahasiswa dan dosen pembimbing. Sehingga ketika muncul persoalan terkait dengan kesulitan bertemu dosen, ataupun lamanya naskah dikoreksi maka tidak ada aturan yang mengikat. Disisi lain kewajiban mahasiswa juga tidak atur secara spesifik sehingga memiliki kebebasan secara luas untuk melakukan bimbingan sesuai dengan keinginannya. Pada kasus dimana mahasiswa 'menghilang' dalam jangka waktu yang lama, juga belum ada konsekuensi ataupun ketentuannya.

Temuan tentang kendala-kendala yang dirasakan mahasiswa selama proses bimbingan skripsi sejalan dengan penelitian Kusnendar yang menyebutkan bahwa faktor pembimbingan dosen menjadi kendala bagi mahasiswa dengan persentase sebesar $75 \%$, yang ditandai degan kesulitan bertemu dengan dosen karena kesibukan dosen, kesulitan dalam memhami masukan, dan kesulitan dalam menentukan langkah selanjutnya. Penelitian 
Wiyatmo juga menyebutkan salah satu faktor penghambat adalah pembimbingan yang meliputi; kesulitan bertemu dosen, perbedaan pendapat pembimbing I dan II, serta kesibukan dosen yang beragam.

Pada perspektif yang agak berbeda, Hasil penelitian Ike Ratnawati menyatakan bahwa profil akademik dosen pembimbing skripsi tidak dianggap sebagai faktor yang terlalu dominan yang diharapkan mahasiswa dapat membantu penyelesaian skripsinya. Mahasiswa mengidentifikasi profil personal/kepribadian dosen pembimbing yang dapat memotivasinya dalam penyelesaian skripsi yakni dosen pembimbing yang perhatian, konsekuen, jujur, komunikasi yang baik, nyaman, lancar, hangat, bersahabat, nyantai, mudah, tidak terlalu formal, tidak terlalu ketat, tidak terlalu birokratis, bisa bersikap sebagai teman yang siap membantu memecahkan penyelesaian skripsi mahasiswa, tegas, disiplin, mudah ditemui di kampus, dan bisa membuat janji di luar kampus sewaktu-waktu mahasiswa membutuhkan. ${ }^{36}$

Keenam, Faktor Aktifitas lain. Berdasarkan angket diperoleh data bahwa 19 dari 29 mahasiswa mengaku bahwa kesibukan dengan aktifitas lain menjadi salah satu kendala dalam penyelesaian skripsi. Artinya 65,5\% mahasiswa mengalami kendala dalam hal aktifitas lain berpengaruh terhadap penyelesaian skripsi, sedangkan sisanya sebesar 34,5\% mengaku bahwa aktifitas lain tidak menjadi kendala dalam penyelesaian skripsinya. Aktifitas tersebut antara lain; bekerja (full time maupun part time), aktif di organisasi kemahasiswaan, aktif dalam organisasi kemasyarakatan, dan membantu orang tua di rumah.

Kuliah sambil bekerja diakui menjadi salah satu kendala dalam penyelesaian skripsi. Kesulitan membagi waktu meruapakan salah

\footnotetext{
36 Ike Ratnawati. Pendapat Mahasiswa Jurusan Seni dan Desain tentang Profil Dosen Pembimbing Skripsi yang dapat Membantu Penyelesaian Skripsinya. Malang: Universitas Negeri Malang. 2007
} 


\section{At-Taqaddum}

Vol. 11 No. 2 (2019) pp 186-233

DOI: http://dx.doi.org/10.21580/at.v11i2.4566

satu penyebabnya disamping faktor kelelahan yang mengakibatkan setelah bekerja sudah enggan untuk mengerjakan skripsi yang berakibat pada tertundanya penyelesaian skripsi.

Hal ini sejalan dengan hasil penelitian yang dilakukan oleh Hartanto, Susanti, dan Maryana yang menyebutkan bahwa salah satu faktor penghambat dalam proses penyelesaian skripsi yaitu berkaitan dengan faktor eksternal yang berupa aktifitas pribadi seperti, kuliah sambil bekerja, kursus, dan mengurus keluarga. ${ }^{37}$

Hasil penelitian tersebut juga didukung oleh penelitian yang dilakukan oleh Wulan dan Abdullah yang menyebutkan bahwa salah satu kendala dalam proses penyelesaian skripsi mahasiswa adalah berkaitan dengan aktiftas lain yang dilakukan oleh mahasiswa yaitu bekerja. ${ }^{38}$ Sebagaimana diketahui bahwa secara manusia memiliki keterbatasan dalam hal fisik dan psikisnya. Setiap aktifitas fisik yang dilakukan membutuhkan enegergi. Semakin banyak kegiatan yang dilakukan, semakin banyak pula energy yang dikeluarkan. Secara fisik, kegiatan kuliah sambil bekerja atau melakukan aktifitas lain, secara sedikit banyak akan mempengaruhi kemampuan fisiknya.

Sementara disisi yang lain, kendala dalam pembagian waktu menjadi persoalan tersendiri. Perkerjaan yang fulltime dan menyita waktu menjadikan mahasiswa tidak memiliki waktu lebih banyak dalam menyusun dan menyelesaikan skripsi. Belum lagi berkaitan dengan focus beban kerja. Pembagian fikiran dan pemusatan perhatian menjadi terganggu jika aktifitas yang dilakukan diluar jangkauan kemampuan fisik dan psikisnya.

37 Hartanto, Susanti, dan Maryana, Analisis Faktor Pendukung dan PenghambatPenyelesaian Tuas Akhir Skripasi Mahasiswa Program Studi Pendidikan Akuntansi FE UNY Angkatan 2011. Dalam Jurnal PELITA Vol. XI No. 2 Agustus 2016

${ }^{38}$ Wulan dan Abdullah, Prokratinasi Akademik dalam Penyelesaian Skripsi dalam Jurnal Sosio-Humaniora Vol 5. No. 1 Mei 2014, pp. 55-74 
Sementara itu, dari sisi motif yang mendorong mahasiswa kuliah sambil bekerja berdasarkan penelitian yang dilakukan oleh Maylana Dirmantoro menyebutkan bahwa adanya motif internal dimana dorongan tersebut berkaitan dengan aktifitas individu dan dilakukan untuk meningkatkan kualitas dari aktifitas yang sedang ditekuni, tidak semata-mata hanya memenuhi kebutuhan fisiologis secara mendasar tetapi juga lebih kepada menjadi manusia yang lebih berkualitas, memiliki daya saing yang tinggi, memaksimalkan potensi diri yang dimiliki, juga untuk inisiasi dan merencanakan karir kedepannya. ${ }^{39}$

Secara ringkas, faktor internal dan eksternal yang menghambat penyelesaian skripsi mahasiswa jurusan BPI dapat ditunjukkan pada tabel berikut

Tabel 2. Faktor Internal yang Menghambat Penyelesaian Skripsi

Faktor Internal

Kesehatan

Hambatan Psikologis

Kemampuan akademik

\section{Bentuk-bentuk}

Kurang fit, sakit kepala, kelelahan

Kemalasan, kurang motivasi, menundanunda, stress, kecemasan

Penguasaan MP kurang, kesulitan dalam menuangkan ide dalam bentuk tulisan, kesulitan/keterbatasan kemampuan tata tulis, kesulitan mengelaborasi permasalahan, keterbatasan kemampuan Bahasa asing, kemampuan baca tulis al quran

Pendekatan (Sikap dan Tidak bisa membagi waktu, kurang kebiasaan belajar) membaca buka, kurang berdiskusi dengan teman, kurang bersungguh-sungguh

39 Maylana Dirmantoro, Motivasi Mahasiswa Kuliah sambil bekerja, Skripsi. Fakultas

Psikologi UIN Maulana Malik Ibrahim Malang, 2015 


\section{At-Taqaddum}

Vol. 11 No. 2 (2019) pp 186-233

DOI: http://dx.doi.org/10.21580/at.v11i2.4566

Tabel 3. Faktor Eksternal yang Menghambat Penyelesaian Skripsi

\begin{tabular}{ll}
\hline \multicolumn{1}{c}{ Faktor Eksternal } & \multicolumn{1}{c}{ Bentuk-bentuk } \\
\hline Keluarga & $\begin{array}{l}\text { Kurang motivasi dari orang tua, kurang } \\
\text { dukungan finansial, tekanan agar segera } \\
\text { lulus }\end{array}$ \\
\hline Lingkungan/teman & $\begin{array}{l}\text { Lingkungan kos yang kurang nyaman, } \\
\text { teman yang sering mengajak 'jalan' } \\
\text { (melakukan aktifitas yang kurang penting), } \\
\text { teman sama-sama malas mengerjakan } \\
\text { skripsi) }\end{array}$ \\
\hline Sistem administrasi & $\begin{array}{l}\text { Mengurus perijinan dan surat menyurat } \\
\text { skripsi }\end{array}$ \\
& $\begin{array}{l}\text { ung memakan waktu, berkas persyaratan } \\
\text { data karena jaringan eror, kendala }\end{array}$ \\
& persyaratan IMKA dan TOEFL \\
\hline Referensi & Kesulitan mencari referensi tema-tema \\
& tertentu, jumlah referensi yang terbatas, \\
& referensi yang tidak boleh dipinjam. \\
\hline Pembimbingan dosen & $\begin{array}{l}\text { Dosen sulit ditemui, aktiftas/kesibukan } \\
\text { dosen yang beragam, lamanya naskah }\end{array}$ \\
& dikoreksi, takut bertemu dosen, kurang \\
mendapatkan masukan dari dosen, \\
perbedan masukan dari pembimbing 1 dan \\
2, kurang bisa memahami masukan dari \\
dosen.
\end{tabular}




\section{Kesimpulan}

Berdasarkan penelitian diperolah kesimpulan sebagai berikut:

1. Ditemukan bahwa ada sepuluh faktor yang menghambat penyelesaian skripsi mahasiswa jurusan BPI FDK UIN Walisongo Semarang. Dari sepuluh faktor tersebut peneliti mengelompokkan menjadi dua bagian, yaitu faktor internal dan faktor eksternal. Faktor internal berupa; kesehatan, hambatan psikologis, kemampuan akademik, dan pendekatan (sikap dan kebiasaan belajar). Sedangkan faktor eksternal berupa; keluarga, lingkungan/teman, sistem admninstrasi skripsi, proses pembimbingan dosen, referensi, dan aktifitas lain.

2. Jabaran masing-masing faktor tersebut yaitu;

a. Kesehatan; kurag fit, pusing, dan kelelahan

b. Hambatan psikologis; Kemalasan, kurang motivasi, menundanunda, stress, kecemasan

c. Kemampuan akademik; Penguasaan MP kurang, kesulitan dalam menuangkan ide dalam bentuk tulisan, kesulitan/keterbatasan kemampuan tata tulis, kesulitan mengelaborasi permasalahan, keterbatasan kemampuan Bahasa asing, kemampuan baca tulis al quran

d. Pendekatan (sikap dan kebiasaan belajar); Tidak bisa membagi waktu, kurang membaca buka, kurang berdiskusi dengan teman, kurang bersungguh-sungguh

e. Keluarga; Kurang motivasi dari orang tua, kurang dukungan finansial, tekanan agar segera lulus

f. Lingkungan/teman; Lingkungan kos yang kurang nyaman, teman yang sering mengajak 'jalan' (melakukan aktifitas yang kurang penting), teman sama-sama malas mengerjakan skripsi)

g. Sistem admnistrasi skripsi; Mengurus perijinan dan surat menyurat yang memakan waktu, berkas persyaratan untuk 


\section{At-Taqaddum}

Vol. 11 No. 2 (2019) pp 186-233

DOI: http://dx.doi.org/10.21580/at.v11i2.4566

ujian yang banyak, kesulitan upload data karena jaringan eror, kendala persyaratan IMKA dan TOEFL

h. Referensi; Kesulitan mencari referensi tema-tema tertentu, jumlah referensi yang terbatas, referensi yang tidak boleh dipinjam.

i. Pembimbingan dosen; Dosen sulit ditemui, aktiftas/kesibukan dosen yang beragam, lamanya naskah dikoreksi, takut bertemu dosen, kurang mendapatkan masukan dari dosen, perbedan masukan dari pembimbing 1 dan 2, kurang bisa memahami masukan dari dosen.

j. Aktifitas lain; Bekerja, sibuk kegiatan organisasi kemahasiswaan dan kemasyarakatan, membantu orang tua di rumah.

\section{Referensi}

Catrunada, Linda, Perbedaan Kecenderungan Prokrastinasi Tugas Skripsi Berdasarkan Tipe Kepribadian Introvert dan Ekstrovert. Jakarta: Fakultas Psikologi Universitas Gunadarma. 2007.

Crow, D. Leatar \& Crow, Alice, Psikologi Pendidikan, Yogyakarta: Nur Cahya, 1989

Dimyati dan Mudjiono, Belajar dan Pembelajaran, Jakarta: Rineka Cipta, 2006

Djaali, Psikologi Pendidikan, Jakarta: Bumi Aksara, 2011

Gates, Arthur J. et. al., Educational Psychology, New York: The MacMillan Company, 1954

Gredler, Margareth E. Bell, Learning and Instruction; Theory into Practice, New York: Macmillan Publishing Company, 1986

Greenberg, Jerald, Managing Behaviors in Organizations, New York: Prentice Hall, 1996 
Hamid, Farid dan A. Rachman. Buku Paduan Skripsi . dalam https://id.wikipedia. Org /wiki /Skripsi. Diakses pada 28 Februari 2016

Harlen, Wyne, Teaching and Learning Primary Science, London: Row Publisher, 1985

Hartanto, Susanti, dan Maryana, Analisis Faktor Pendukung dan PenghambatPenyelesaian Tuas Akbir Skripasi Mahasiswa Program Studi Pendidikan AkuntansiFE UNY Angkatan 2011. Dalam Jurnal PELITA Vol. XI No. 2 Agustus 2016

Ibrahim, dkk, Kurikulum dan Pembelajaran, Jakarta: Rajawali Press, 2012

Julita dkk. Faktor Penghambat dalam penyelesaian Skripsi Mahasiswa Jurusan Kesejahteraan Keluarga. Padang: Universitas negeri Padang, 2015.

Kingsley, Howard, The Nature and Condition of Learning, New Jersey: Prentice Hall Ings Engliwood Clift, 1957

Kusnendar, Febriyanto, Suwachid, dan Danar Susilo Wijayanto. 2012. Analisis Penghambat Penyelesaian Studi Mahasiswa S1 Program Studi Pendidikan Teknik Mesin Jurusan Pendidikan Teknik dan Kejuruan Fakultas keguruan dan Ilmu Pendidikan Universitas Sebelas Maret Surakarta.

Makmun, Abin Syamsudin, Psikologi Kependidikan, Perangkat Pengajaran Modul. Jakarta: Remaja Rosdakarya, 2001.

Mappiare, Andi, Psikologi Orang Dewasa, Surabaya: Usaha Nasional, 1983

Narbuko, Cholid dan Abu Ahmadi, Metodologi Penelitian. Jakarta: Bumi Aksara, 2005

Pai, Anant, How to Develop Self-Confidence. Singapore: S.S Mubarak and Brother, 1996

Purwanto, Ngalim, Psikologi Pendidikan, Bandung: Remaja Rosdakarya, 2007 


\section{At-Taqaddum}

Vol. 11 No. 2 (2019) pp 186-233

DOI: http://dx.doi.org/10.21580/at.v11i2.4566

Putri dan Savira, Pengalaman Menyelesaikan Skripsi: Studi Fenomenologis pada Mahasiswa Psikologi Universitas Negeri Surabaya, dalam Jurnal Character. Volume 02 Nomor 02 Tahun 2013

Ratnawati, Ike, Pendapat Mabasiswa Jurusan Seni dan Desain tentang Profil Dosen Pembimbing Skripsi yang dapat Membantu Penyelesaian Skripsinya. Malang: Universitas negeri Malang. 2007.

Rismen, Sefna, Analisis Kesulitan Mahasiswa dalam Penyelesaian Skripsi di Prodi Pendidikan Matematika STKIP PGRI Sumbar, dalam Jurnal LEMMA, Vol. 1 No, 2. Mei 2015.

Shaleh, Abdul Rahman. Psikologi: Suatu Pengantar dalam Perspektif Islam, Jakarta: Kencana, 2008.

Siswanto, Ibnu dan Yoga Guntur Sampurno, Faktor-faktor Penghambat Penyelesaian Tugas Akbir Skripsi Mahasiswa Pendidikan Teknik Otomotif FT UNY. Yogyakarta: Universitas Negeri Yogyakarta.

Slameto, Belajar dan Faktor-faktor yang Mempengarubinya. Jakarta: Rineka Cipta, 2010

Sugiyono, Metode Penelitian Pendidikan Pendekatan Kuantitatif, Kualitatif dan R $\ll$ D. Bandung: Alfabeta, 2007.

Suryabrata, Sumadi, Psikologi Pendidikan, Jakarta: Rajawali Press, 2004

Syah, Muhibbin, Psikologi Pendidikan, Bandung: Remaja Rosda Karya, 2010

Winkel, Psikologi Pengajaran. Yogyakarta: Media Abadi, 2005

Wirartha, Pedoman penulisan usulan penelitian, skripsi, dan tesis, Yogyakarta: Andi Offset, 2006.

Wittaker, James O., Introduction to Psychology, Tokyo, Toppan Company, 1970

Wiyatmo ,Yusman, Mundilarto, Suharyanto, dan Eko Widodo, Efektivitas Bimbingan Tugas Akbir Skripsi (Tas) Mahasiswa Jurusan Pendidikan Fisika FMIPA UNY, dalam Prosiding Seminar Nasional 
Penelitian, Pendidikan dan Penerapan MIPA, Fakultas MIPA, Universitas Negeri Yogyakarta, 15 Mei 2010

Wulan, Dyah Ayu Nur dan Sri Muliati Abdullah. Prokrastinasi Akademik dalam Penyelesaian Skripsi. Dalam Jurnal Sosio-Humanira. Vol 5. No. 1 Mei 2014. pp 55-74 